'IT SAVED THEIR LIVES': EXPLORING FEMINIST PARENTING PRACTICES

by

Shelleena Maidment, BA, University of Guelph, 2012, BSW, Ryerson University, 2016

\author{
An MRP \\ presented to Ryerson University \\ in partial fulfillment of the \\ requirements for the degree of \\ Master of Social Work \\ in the Program of \\ Social Work
}

Toronto, Ontario, Canada, 2017

(c) Shelleena Maidment 2017 


\section{AUTHOR'S DECLARATION FOR ELECTRONIC SUBMISSION OF A MRP}

I hereby declare that I am the sole author of this MRP. This is a true copy of the MRP, including any required final revisions.

I authorize Ryerson University to lend this MRP to other institutions or individuals for the purpose of scholarly research

I further authorize Ryerson University to reproduce this MRP by photocopying or by other means, in total or in part, at the request of other institutions or individuals for the purpose of scholarly research.

I understand that my MRP may be made electronically available to the public. 


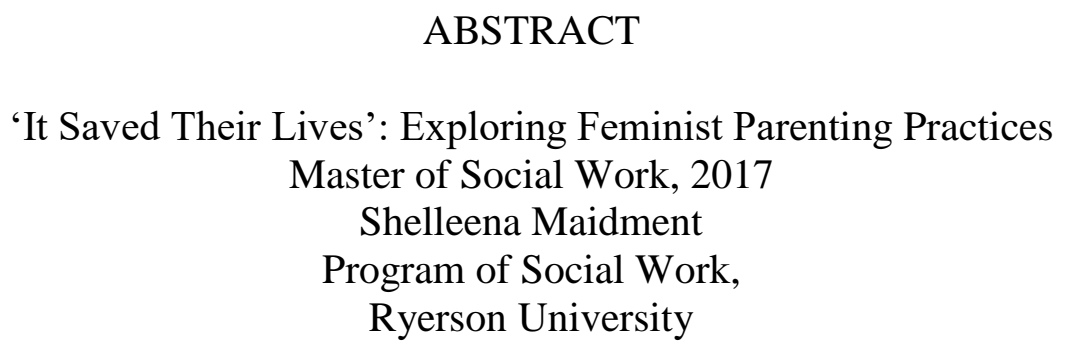

This study explores the practices of feminist parenting and looks at practices that feminist parents use to raise children outside of patriarchal parenting designs that enable and perpetuate sexism, gender and sexual binaries, ageism, heterosexism, and performance of societal norms. My research is being guided by two related questions. (1) What are the current practices that feminist parents are utilizing to raise critically engaged, socially conscious children? (2) Why they choose to be or why they feel it is important to be a feminist parent? I am imploring a qualitative design, specifically guided by feminist narrative research to engage in face to face interviews with self-identified, feminist parents to capture both questions. The benefits of this research are to build the literature around feminist parenting, and continue the important conversation of raising critically conscious children. This project explores the actual practices of how parents are engaging in feminist parenting in successful ways. The hopeful outcomes for this study is to add to the research surrounding feminist parenting and to illuminate the strengths of parenting in a feminist informed way. 


\section{ACKNOWLEDGEMENTS}

I would like to express my great appreciation to my research supervisor, Dr. Susan Preston, for her patience and flexibility as well as her constructive feedback during the process of this research. Her time and advise, in regards to this research has been greatly appreciated.

I would also like to bestow my greatest and humble thanks to all of the participants of this study for the generous offering of their time, wisdom, honesty with this project. It was a real gift to me to be given the opportunity to listen to the narratives of these four brilliant, strong, resilient and frankly, kick ass women.

Finally, I wish to thank Chris Hackett for his incredible support, this, nor I would be here without you. 


\section{DEDICATION}

To any future people that I bring into this world, I hope to give you the grounding, strength and insight that these four women, in the pages to come, have gifted their children. 


\section{TABLE OF CONTENTS}

Chapter 1: Introduction

Page 1

Chapter 2: Theoretical Framework

Page 4

Chapter 3: Literature Review

Page 8

Chapter 4: Methodology

Page 23

Chapter 5: Findings

Page 28

Chapter 6: Discussion

Page 52

Chapter 7: Conclusion

Page 63

Appendices

Page 65

References

Page 71 


\section{LIST OF APPENDICES}

Appendix A - Recruitment Flyer

Appendix B - Consent Form

Appendix C - Interview Questions
Page 65

Page 66

Page 70 


\section{Chapter 1. Introduction}

I am at an age in life where my husband and I are constantly getting asked, 'When are you having kids?' and truthfully, we haven't had an answer. We have gone back and forth for a couple of years, debating whether or not we want to have children. Recently, we came to a decision that we do. Well I think this decision plagued me even more than the deciding. I have learned so much throughout my undergraduate career about society and the world at large. Through my sociology degree, I learned that I was a feminist by truly understanding how patriarchy disenfranchises women all over the world. Through my social work degree, I learned that I am going to do something about it. Going back to the decision that my partner and I made, I know that I cannot raise my children without pouring my knowledge of the world into them, as well as raising them with an understanding of oppression, privilege and power relations. I realized I am going to have to embody my feminism, as a parent. This left me with a lot of questions, the first being, what practices do feminist parents engage in, to raise socially conscious, critically informed children? This question came to be because I believe that feminist informed parenting would cultivate children to be more socially aware of issues pertaining to society and raise their critical wakefulness. This question mobilized me into wondering how parents undertake child-rearing through a feminist-informed approach. Therefore, I thought it would make an insightful and intriguing MRP topic. Thus, I have explored the everyday practices of feminist parenting and how these parents resist against dominant notions of parenting.

This is not only important to me, but to social work as a whole. Utilizing an antioppressive perspective within social work, it is crucial to support social justice and interrogate the very distinct power relations that become hurdles when navigating through the social world. 
To raise the next generation with a feminist and equitable lens could transform society at large. To locate how certain parents make space for critical and transformative conversation with their children is essential to furthering these discussions in many more homes, schools and communities. When considering radical, transformative social work, it is imperative to seek change and mobilize individuals. I couldn't think of a better place to start than in the home.

To walk you through this paper, we will first start with the theoretical framework through which I am going to be viewing this topic. Transfeminism (Koyama, 2001) grounded this study and is the lens I used, to appreciate and examine the sea of knowledge situated around me and this topic. We will then unearth the scholarship around the issue of feminist parenting. The literature revealed many integral issues around this topic. This paper navigates us through some main themes embedded within feminist parenting. The journey begins with exploring the system of motherhood, and the need for restructuring, to be inclusive of diverse understandings of mothering and further, parenting. We then discover that feminist parenting is seen as a political act. This leads us to appreciating that feminist parenting is a continual fight against the institution of motherhood and patriarchal designs of parenting. We continue this voyage in examining how feminist parenting is a form of resistance, by engaging in anti-sexist and gender neutral forms of parenting. We conclude with how we can incorporate these practices into critically conscious parenting.

Once we receive the grounding from the literature, we will move into the methodology that I utilized within this qualitative research study. When undertaking research around feminist ideologies and practices, it is critical that my methodology respect those values. Therefore, we will explore how I used intersectional narrative feminist research (Fraser \& MacDougall, 2016) to guide my research design. It is my belief that my theoretical framework, literature review and 
methodology discussion create a research approach that allows me to illuminate the importance of the topic of feminist parenting and the need for more dialogue around critically engaged, informed parenting. Once grounded by the methodology of this study and how the study is situated, we will then delve into the findings from this study. I introduce the four women that took part in this process by discussing their feminist identities and how they have navigated the world. I then frame their narratives into several common themes that emerged from my interviews with them, surrounding their practice of feminist parenting. We explore three big areas: why these women chose to parent in a feminist informed way, what their actual practices or strategies of feminist parenting are and lastly traversing the outcomes that they have observed within their children.

Lastly, we move into the discussion where I comment and navigate through my findings and make associations to the literature. I also discuss the strengths and limitations of this study as well as my implications for social work and how feminist parenting connects to practice, and lastly, my recommendations for further research within feminist parenting. 


\section{Chapter 2. Theoretical Framework}

Introducing my topic and the way I am viewing it, mobilizes me to introduce myself; situating myself within my theoretical framework is vital to understand why I am choosing transfeminism as my lens. I believe in feminism and the equitable treatment of men and women socially, politically and economically. I benefit from this definition of feminism, as I am a white, middle-classed, able-bodied, cisgender woman. Due to my lived experiences however, I need to further this definition. I was raised by two women, in a same sex relationship. Growing up my mother's partner was in a female identified body; however, she did what she could, in her use of clothes, haircut and bodily performance to resist against a female identity. During my teen years, my mother's partner told us that she identified as transgender, and had always wanted to be a man. Therefore, growing up in a household that gave space for various identities, I realized that not all women benefit from the discourse of white, heterosexual, cissexual feminism.

Having the positionality that I possess, as well as identifying as a pansexual woman, the topic of gender and sexuality is always on the forefront of my thoughts and critique. Hence, in doing this research on feminist parenting, it was important to use the appropriate and most inclusive theoretical framework. Reading Julia Oparah's (2012) article and seeing the atrocious, excluding practices that feminist organizations extend toward the transgender community, prepared me to go beyond feminism as a resource. The way that 'women only' spaces have enacted rules of 'women born women' has perpetually othered transmen and transwomen (Oparah, 2012). I did not want to create that kind of space within my research. Therefore, I found transfeminism which "aims to counter the homogeneity of the white, straight, and abstract subject of feminism. As did lesbian feminists, feminists of color, queer feminists, and cyber feminists before us, trans people are fighting feminism's exclusionary tendencies" (Espineira \& 
Bourcier, 2016, p. 86). Therefore, due to my subjectivity, I looked for something that attempts to create a space for all identities, and sees gender and sexuality as more fluid than static; but still has the critical lens of dismantling patriarchy and sexism, along with other structural means of oppression.

Needing to cultivate a critical feminist lens, I utilized transfeminism as my theoretical framework through which I viewed my topic and research. Transfeminism has come from a few different scholars. I mostly relied on Emi Koyama's (2001) work, as well as scholars from Latin America and France. When looking for scholarship on transfeminism, I did find quite a few articles from Latin America; however, some of them have not been translated into English so I could not read them. However, Koyama (2001) has written accessible literature on transfeminism, and pulling from a few other scholars, I do believe I was able to get a rich textual understanding of this framework.

Transfeminism is "a powerful, creative intervention into our ways of being in the world, in that it goes beyond binarism and the essentialism of identities" (Silva \& Ornat, 2016, p. 221). There is a need, especially in feminist spaces to create room for female identifying people, as well as an understanding that gender does not live in binaries. Most feminist organizations rely on rigid gender binaries; this needs to be expanded and furthered by understanding lived experiences of gender non-conforming, gender non-binary and genderqueer people. Transfeminism challenges traditional notions of feminism and attempts to advance feminist thinking. Koyama (2001) discusses that when a group of women whose identities have formerly been subjugated, start to speak out, it challenges other feminists to think about inclusivity. This creates a space that Wong (2004) thoroughly discusses, about knowing through discomfort. Sometimes very meaningful dialogue and conversation that ignite change is started by 
discomfort and an understanding of oppressive thoughts. Koyama (2001) discusses that this usually "leads to a painful realization of our own biases and internalized oppressions as feminists, it eventually benefits the movement by widening our perspectives" (par. 2).

The reason that this framework works so well with understanding feminist practices of parenting is that the principles of transfeminism are very critical and inclusive. Within The Transfeminist Manifesto, Koyama (2001) discusses the beliefs very clearly, starting with allowing people to define themselves, and make individual choices regarding their own gender and sexual identity and expression. Transfeminism also requires an understanding that both sex and gender are socially constructed and produced; and laterally attempts to disrupt essentialist conceptions of cisnormativity, heteronormativity and homonormativity. Transfeminism also positions itself by confronting social and political institutions, by supporting the anti-oppressive principle of critical reflexivity around one's privileges and the diverse intersectionalities we face, as well as how we benefit from all of these systems. Lastly, this framework looks forward to a time in society when trans people's presence is no longer seen as problematic in public spaces.

Although I did not reach out to only trans identifying people for this research, I find this framework to be indispensable due to its critical analysis and view of gender and sexuality, as well as its potential for furthering the feminist rhetoric and finally making space for all bodies to exist. This theoretical lens prepared me for the possibility that I might have research participants who may identify beyond the essentialist boundaries of male and female. As well, any of the children that the parents in this study are raising may have fallen into non-conforming spaces and I wanted there to be room in my lens for inclusivity to all identities.

With this research, I am motivated to tackle systemic issues, in a way that dismantles binaries and labels and is strengthened by inclusivity; the transfeminist approach is very relevant 
and most strongly supports and informs my work. When looking at raising children while resisting dominant narratives that are embodied by patriarchy, I want to recognise what the alternative or counter discourses are, and this framework will allow me to explore that thoroughly. To understand the alternative discourse that these parents are working from, I needed to comprehend the systems that the parents are resisting against. Transfeminism assisted me throughout the discovery and interrogation of normativity, institutionalized gender systems, gender performativity, sexism, misogyny, white supremacy, patriarchy, pathologizing of deviant gender expressions and societal expectations and norms. Along with these systems of oppression, we also need to take feminism further; Serano (2007) discusses,

it is not simply enough for trans activists to challenge binary gender norms... we must also challenge the idea that femininity is inferior to masculinity and that femaleness is inferior to maleness. In other words, by necessity, trans activism must be at its core a feminist movement (p. 16).

To create space for all identities within this study and to advance and broaden the dialogue of traditional, white, feminism, with a special focus on gender and sexuality we need to, "let transfeminism be the food that strengthens us in order to invent worlds that are possible, and that go beyond the current destructive order of gender" (Silva \& Ornat, 2016, p. 225). Transfeminism has informed my work, aiding me to develop my questions for my interviews, by asking specific questions around sexuality, gender and body image and how parents navigate through the oppressive systems that I mentioned above. Transfeminism also supported me through my interviews and analyses to keep me challenging and resisting distinct boundaries and labeling that are intrinsically learned in this society. 


\section{Chapter 3. Literature Review}

The literature revealed many integral topics around feminist parenting. This section navigates us through some main themes embedded within feminist parenting. The journey begins with exploring the system of motherhood, which needs restructuring from diverse understandings of mothering and parenting. We then discover that feminist parenting is seen as a political act. This leads us to appreciating that feminist parenting is a continual fight against the institution of motherhood and patriarchal designs of parenting. We continue by examining how feminist parenting is a form of resistance, by engaging in anti-sexist and gender-neutral forms of parenting. We conclude with how we can incorporate these practices into critically conscious parenting.

\section{The Institution of Motherhood}

To recognise why we need to shift our understanding toward feminist parenting, we need to comprehend how patriarchal confines of mothering have been detrimental to both women and men in parenting roles. Green (2009) discusses that "the social construction of motherhood is a narrow and limiting ideal that does not encapsulate the complexity of the experiences of women who have children" (p. 85). bell hooks (2015) also discusses that motherhood as an institution has left out so many voices and experiences from its constituency, because it was working within the confines of white supremacy, heteronormativity, patriarchy and heterosexism that was very heavily dictated by class. Green (2009) makes visible a problematic notion of women, "the 'ideal' mother is a middle-class, heterosexual married woman who takes on the qualities associated with the stereotypical wife" (p. 87). These narratives create room only for singular stories that are framed by class, race and heteronormativity, not even mentioning the ones that are left out of this narrative. 
To discuss power relations within these boxes recognizes the fact that these duties reflect and reproduce sexism in the household. Many authors discuss the detriments of this infantilized ideal mother but Green (2015) points out that it serves "the interests of neo-liberal, white supremacist, capitalist patriarchy" (p. 199). It serves these interests because it perpetuates this notion that women need to stay in the household, where their work is undervalued and deemed unworthy in neo-liberal or capitalist ways. This creates very strict labels for women and men as well.

What is harmful about this discourse is dissected throughout the literature. The women that attempt to squeeze into these boxed-in sexist roles seem to have more mental health issues; for the women that do not, Green (2015) discusses, that they fit into the 'deviancy discourses' [that] stem from this ideological construct of mothering, which are used to target women who don't conform to the script of full-time biological motherhood. For instance, mothers who are immigrants, single, racialized, disabled, lesbian, queer, trans, living on social assistance or welfare are frequently subjects of deviancy discourses of mothering, and of its ill effects (p. 199).

Much literature distinguishes the details of motherhood which "refers to the oppressive patriarchal institution that is male-defined and controlled" whereas "mothering refers to women's experiences of mothering that are female defined and centred and potentially empowering to women" (Wu, 2012, p. 44). Historically however, these mothering experiences were usually given a universal narrative of the ideal experience of white, stay-at-home mothers, that we discussed above. It has only been recently that subjugated voices - women of colour, lesbian and trans women and other women - have been able to tell their stories and their experiences and defy the essentialist notions of patriarchal motherhood and the women's 
liberation movement. (hooks, 2015; Mack-Canty \& Wright, 2004). In discussing this, we need to recognise that white women are very much implicated in silencing these knowledges and in turn, furthering oppression of these women. We, as white women have benefitted from this historical act in many ways.

This is again why feminism needs to be furthered by the frameworks of intersectionality (Fraser \& MacDougall, 2016) and Transfeminism (Koyama, 2001). These advance the thought of who and what feminism represents and attempts to fill major gaps in the narrative of mothering. These approaches, along with critical feminism help us unpack the discourses that patriarchy has pounded on us for so long and appreciate the diversity of families, parents and women around us. This type of dismantling will widen our perspectives when it comes to what constitutes a family (Mack-Canty \& Wright, 2004; Schmeiser, 2011) and also how we raise our children to interact with the world.

There is a long history between feminism and mothering, which I have touched on in the pages above. Feminism can have singular ways of analysing motherhood and strong opinions on whether women should partake in this institution. Including the voices of marginalized women has helped to expand the notions of mothering and parenting, and has helped to understand these experiences through the lens of intersectionality. Utilizing a critical lens when exploring dominant beliefs of motherhood is essential to resistance. We need to understand the system, to have the ability to dismantle and defy it; and begin to rewrite it from a choir of experiences, as opposed to a solo performance of whiteness.

\section{It is a Political Act}

When we discuss dismantling the system with feminism, we need to comprehend that feminism is about linking the personal and the political (Fraser \& MacDougall, 2016; Koyama, 
2001). This is the concept that has made feminism so powerful and has progressed consciousness raising. When we learn that what we do as individuals has larger systemic influences, we realize the need for this view; individuals can make change or maintain the status quo. Transfeminism (Koyama, 2001) furthers this understanding by exposing the societal and institutional elements and suggests to confront them and challenge yourself to explore the way we internalize features of society. This is an excellent example of connecting the personal to the political.

In the introduction to Green's (2006) article, Developing a Feminist Motherline: Reflections on a decade of feminist parenting she articulates,

Feminism is not only central to their personal identity as women; feminism is essential to their philosophies for and practices of parenting. For these women, feminist mothering is a conscious political strategy they use to bring about social change in their lives and in the lives of their children. (p. 8)

Many authors reiterate the fact, that since feminist parents are raising their children in socially engaged ways, they are engaging in a political act (Green, 2009; 2015; Schmeiser, 2011; White, 2006; Wu, 2004). Green (2009) states, each of the women I spoke with believes her mothering to be a feminist act. Inherent then, in this political act, is challenging the expectations placed upon them as mothers to teach their children about injustices and various forms of oppression (p. 91).

A topic throughout this theme is that the political act also can involve engaging in critical discussion with children to learn about oppression and power relations. This is reiterated in White's (2006) article, where she observed that African American feminist fathers were engaging in politically conscious parenting by, "actively rais[ing] their kids to oppose racist, sexist, and heterosexist beliefs and practices" (p. 56). This is the act of conveying and 
embodying political ideas and values in your parenting style and the world outlook you are sharing with your children.

Other authors believed that different aspects of the parenting took on a political presence. Schmeiser (2011) shares her experiences as a woman, in a same sex relationship, raising a son with feminist ideals. She considers the political act is just the existence of her family; "our struggle to have our family recognized as such (and in our case, having also required legislative amendments) may also serve at the same time to transform what is recognizable in our culture" (p. 151). This impression that just having a non-normative family structure could be political is reiterating the fact that we live in a society that survives on patriarchal concepts of family.

This is a situation that brings forth my positionality; I was raised in a family with same sex parents. I can echo the above passage when I say that in my small town, our family was indeed non-normative, but also political. I had to defend our family against dominant ideals of what creates a family and who creates a family. These were incredible patriarchal and heterosexist philosophies that I was having to shield us from. Growing up in the family that I did, I became an advocate and an activist, I had no choice. There was no room for my family in the context that existed. We had to make room for ourselves. I can say proudly and passionately that I share the outlook of the author above, because I do believe our existence shifted the mold. However, in saying that, this is why we need to change the rigid, uniform assumptions about family, and I think feminist parents are bulldozing that path.

Another way in which the authors have discussed politically conscious parenting was through the father (hooks, 2015; White, 2006; Wu, 2004). I want to briefly say, this is in a heteronormative situation. Some of the discussion in these articles (hooks, 2015; White, 2006; $\mathrm{Wu}, 2004)$ were entrenched in heteronormative dichotomies when examining the need for fathers 
to be an equal parent. I would like to propose that equal parenting should occur in all families, regardless of the demographics. Wu (2004) discussed that “mothers' political activism exhibited in various aspects in social life (including the anti-sexist and anti-racist way in which they bring up their children); and their expectations of the fathers of the children to share childcare in their everyday lives" (p. 144). We will discuss fatherhood in the pages below, as it is embedded in another main theme but I did want to mention it here, as we need to consider the fact that to some people, engaging the father in parenting is radically political.

This relates to the first theme in how the architecture of motherhood as an institution is powerful and engrained in historical context. It needs to be contested and disassembled by engaging in political conscious parenting so that all parents, especially men (as historically parenting is seen as a woman's labour of love) have room to sit comfortably in that space. Keeping this in mind, Green (2015) reminds us that "while personal commitments to changing institutional motherhood and mothering practices are needed, they alone are not enough to make substantial change. Larger economic, cultural and social institutions and systems must support them" (p. 204). There is a need to think and act politically, as we are not just building a home, we are rebuilding an entire system.

\section{Fight Against Patriarchy}

There was also a reoccurrence of opinion within the literature that feminist parenting was a continual fight against patriarchal designs of parenting (Green, 2006; 2005; Ott, 2011; White, 2006); "where they consciously intertwine their feminism and mothering, making it a site of resistance to patriarchal constructions of motherhood" (Green, 2009, p. 86) and making visible counter discourses of parenting. These designs are briefly dissected in the first theme around the confines of motherhood and are reiterated in the resistance of feminist parenting being a political 
act against the system. The system we are discussing includes the patriarchal notions of parenting, mothering and familial space. In her article, Feminist Mothering of Sons: Ethical practices for everyone, Ott (2011) explains "I'm raising my children for the common good" and goes on to say, "I would say that is feminist parenting... It signals an ethical practice and value set that go against dominant cultural forms of patriarchal (and racist, heterosexist) parenting” (p. 143). We need to investigate these structural oppressions and understand how they take up space within the home. Patriarchy and heterosexism, along with many other societal dominations, can be seen seeping into the home through many ways: the mother is always seen through the male gaze (Friedman, 2014); how we raise children based on gender (Mack-County \& Wright, 2004; May, 2011; Ott, 2011; Wu, 2004); the concept that certain genders are responsible for certain obligations, for example women and cleaning (Green, 2015; hook, 2015; Mack-County \& Wright, 2004; White, 2006) and lastly, the implications of internalized sexism and oppression in women (Green, 2015; hooks, 2015; Koyama, 2001).

In her article, African American Feminist Fathers' Narratives of Parenting, White (2004) talks to African American fathers that self-identity as feminists. In this article, they do discuss feminist parenting in terms of sex and gender inequalities; but the intersection of race with the fathers also plays a role in the marginalization they face and therefore an Anti-Racist lens is used as well. She states that "as African American feminist men challenge society's expectations about their parenting roles and practices, they specifically have to confront the powerful effect on their children of patriarchal beliefs and assumptions outside the home" (p. 58). This explores other forms of systemic violence, like white supremacy and racism which perpetuate harmful stereotypical ideals of marginalized people. As feminist parents, we need to expand our 
worldview to look at all oppressions, as this is the only way to tackle and dismantle patriarchy and other systemic forms of violence and subjugation.

There are many stereotypes of feminists, including feminist parents. This is explored by Liss and Erchull (2012) when looking at the attitudes toward and misperceptions of feminist parents. The fact that feminism is a bad word or that it brings negative connotations illustrates how patriarchy has entrenched our society so deeply. This article shows how larger, dominant, fundamental beliefs of women identified people manifest on a personal level to create negative attitudes, like misogyny and to perpetuate patriarchal ideals. It is due to these beliefs and essentialist conceptions that feminists and feminist parents alike need to expand feminism (hooks, 2015; Koyama, 2001) and create a space where mothers and parents can rebuild and restory the experience of anti-sexist parenting, equal parenting and feminist parenting (Green, 2006; hooks, 2015; Mack-County \& Wright, 2004).

It seems that people that identify as feminist parents have an understanding of the structural and dominant discourses that inhibit men and women to live without being socially constructed, produced and essentialized. It is this social production that needs unravelling, to get to the underlying problem of the construction of rigid, binary identities. Feminist parents are utilizing their social locations as parents, and their subjectivity as feminists, to inform their children of these discourses and model resistance, critical thinking and social engagement. One way to make known these styles of parenting is by challenging androcentrism (Fraser \& MacDougall, 2016) and including women's and feminist parent's voices of experience. Green (2006) discusses this very notion and names it 'feminist motherline', noting the importance of a feminist motherline to carry the voices, wisdom, and wit of feminist mothers. A feminist motherline assists mothers in re/claiming their feminist mothering 
authority and grounds them in their knowledge and the knowledge of other feminist mothers. It also strengthens, and provides, for some, a foundation for the ongoing political activism of feminist mothers (p. 8).

Continually, a motherline ensures that feminist mothers have a connection with a world view that is centred and draws upon feminism's crucial gender based analysis of the world -including parenting. It also promises a legacy of feminist mothering and motherwork for others (Green, 2006, p.18).

This is what re-storying looks like, this is leaving a historical footprint and path for those who follow and creating an alternative to normative parenting styles. By utilizing this to raise the critical conscious, we can shift the way society sees parenting altogether and reiterate the fact that knowledge is multiply located.

\section{Resistance}

When I say resistance, I mean in many ways. Some ways we have already discussed above, like resisting patriarchal designs of parenting or resisting harmful stereotypes. A few others we will discuss below are: the fact that women need to resist against heteronormative, gendered ideals of parenting (Green, 2015; hooks, 2015), resistance against gender and sex binaries (Green, 2015; Koyama, 2001; Mack-County \& Wright, 2004; Ott, 2011; White, 2006) and parenting from a rigid gender hierarchy. These are all models of resistance against normative approaches of parenting and mainstream thought.

hooks (2015) discusses the fact that as a society, we have normalized the ideal that women are better, more important parents. We see women as a more central figure to the child, based on physiological aspects of the pregnancy and birth and this escalates the woman in her 
role as a parent, far outreaching that of the father. This is discussed in hooks' (2015) chapter, Revolutionary Parenting and she states "men will not share equally in parenting until they are taught, ideally from childhood on, that fatherhood has the same meaning and significance as motherhood" (p. 137). It is pointed out that this goes back to the dictionary definitions (hooks, 2015) of mother and father and how they are defined so distinctly different. Women are seen as a nurturer whereas men are seen as having to take responsibility. These definitions are constructed by societal norms and internalized by many individuals, which perpetuates the dichotomous, gendered, parental styles.

Another excellent point that hooks (2015) examines is the fact that the onus for parenting usually falls on women as well. It is integral for feminist parents to be critically reflective and acknowledge how we benefit from dominant power relations. We need to see why so many women and parents fall into the normalized way of having the distinctive relationship between parents. hooks (2015) proposes "men are socialized to avoid assuming responsibility for childrearing, and that avoidance is supported by women who believe that motherhood is a sphere of power they would lose if men participated equally in parenting” (p. 140). As an oppressed and exploited community, women sometimes try and cling to whatever power they believe they may have, especially in a relationship, particularly with men. This is a downfall to parenting at large, as men will never do an equal amount of responsibilities if women do not demand it of them or they are not socialized to (hooks, 2015).

I think these points clarify and progress the conversation; however, I am concerned over the lack of space in her pages given for families with LGBTQ+ parents, or single mothers. There is a large emphasis on men and fathers and from my positionality, this chapter seems to lack a wider perspective or definition of family. It was helpful for me to use Koyama's (2001) work on 
transfeminism to travel through the contextual gaps that existed here. I believe the wider we dwell, the better we will be able to resist, dissect and demolish normative, gendered parenting. We live in a society that has a very inflexible gender system. These ideals suffocate parents raising children, because anything out of the normative labels is seen as deviant. This deviance is usually pathologized; making identities into disorders. Many feminist parents have a much more fluid thought process around gender and sexual expression. The literature brings forward one example of the implications of being a feminist parent, yet does so while still working within a societal gender binary. May (2011) brings her own experience when sharing about her gender non-conforming son, and how he is seen through an adult lens of severely strict sex and gender roles,

most often adults who need to "explain" Luke to me have made well-meaning assertions that he is clearly gay. By collapsing his non-normative gender presentation with a presumed homosexuality, only two possible options are allowed for his gender: a "regular" heterosexual male or a "non-normal" gay male. Even when supportive of both options, this particular framing creates another binary that fails to recognize multiple male gender presentations not tied to a particular sexuality (p. 130).

This lack of fluid understanding shows the need for acceptance and support around this issue. Feminist parents that give the options of different colours and toys, not based on gender (May, 2011; Wu, 2004) but on pure choice, is what we need in society, as a start. Society needs to stop constructing women and men into such definite categories, and feminist parents are where we see that in action. May (2011) had such a powerful discussion in her article about consistently making visible her perspectives on injustices within societal constraints, to her son; she said 'by living in ways that challenge 'normal,' he has developed a sharp tongue in 
repudiating the 'stereotypical' " (p. 132). It is the need for feminist parents, like Stephanie May to resist and teach resistance as well as be a model for other parents.

\section{Strategies and Practices}

Throughout exploring the literature, I came across quite a few articles that actually had feminist parenting practices, from either their research or theories based on past experience. I wanted to include these in my themes, because I think it is integral to theorize and conceptualize why society needs to change and why we need to participate in feminist parenting; but equally important to know how to do this. Many of the authors had strategies and I want to give voice to as many as I can, as this is the center to my research.

The first theme that emerged from the pages was that of power-sharing (Green, 2006, 2015; hooks, 2015; Mack-County \& Wright, 2004; Ott, 2011). This came through many mediums; one that was mentioned in Green (2006) was having honest communication through building trusting relationships. This was seen by children getting more autonomy and selfgovernance and allowing them to be a part of the conversation, shaking up normative approaches that children are told what to do and have no voice in the relationship with their parent. Powersharing was also seen in parents promoting children to lead in decision making (Mack-County \& Wright, 2004; Ott, 2011) in their own lives. This also manifested in parents being less strict and having less rules, but giving more guidance and engaging in ongoing discussions of values (Green, 2006). This correlates well with feminist theory, wherein autonomy over our own bodies and understanding concepts like consent are easier if you have always had control and say over your body and inclusively your decision making.

The second theme that was explored within several articles was the fact of critical thinking (Green, 2006; May, 2011; White, 2006) with children. We have discussed this briefly 
above, but it is a very important concept. This is what gets children thinking and assessing structures, situations, oppressions and injustices. May (2011) discusses how having dialogue with children, doesn't need to be a university lecture or an anti-oppressive course rather, the need for simplistic understanding is important; she states, "teaching children, even teenagers, to think beyond binaries of "good" and "bad" into nuances of complex systems is not an easy task (p. 132). Having that dialogue will help children to first understand systemic failures and oppressions and then help children to resist against them. Also, getting children to see where they stand due to their subject position and understanding how power changes in context is important so that they can see how and when they are implicated in the system.

To aid the discussion, Green (2009) found that feminist parents were "choosing material, whether videos, books, magazines or toys, that provide various examples of gender, race and sexuality" to spark conversations "about the instances of stereotyping, marginalization and negative depictions of people when they appear" (p.92). These are great ways to ignite these discussions at home or in the community, as well as giving parents a platform to ask questions and share viewpoints.

One theme that materialised and I personally had never thought of, was collective parenting (Green, 2015; hooks, 2015; Ott, 2011). Green (2015) discusses how this concept is central to the Indigenous and Black communities and this community-based childcare should be integral to the way everyone thinks of parenting. This was also brought forth by hooks (2015) who discusses the historical context of this supportive parenting style. She also discusses that "this form of parenting is revolutionary in this society because it takes place in opposition to the idea that parents, especially mothers, should be the only child-rearers" (2015, p.144). This is again a strategy for feminist parents to utilize. White (2006) agrees that supportive social 
arrangements were integral to the feminist fathers she interviewed. Also, if you get a community that believes in feminist parenting, that is also a large social support as the weight will not fall only onto you as parents. This can also help to destabilize the dominant discourses from institutions that perpetuate structural oppressions, like educational systems.

The last important theme that I am going to outline comes mainly from White (2006) which puts forth the importance of fathers to annihilate stereotypical gender roles by nurturing and expressing love to their children equally, with their other parent. Also proving to be important is to be equal role models (Mack-County \& Wright, 2004) for the children, to see both parents participate in equal amounts of work, housework and time with children. This is integral to their upbringing and who they acknowledge as role models. When conversing about raising her son, Schmeiser (2011) concludes with,

like all feminist mothers, I will strive to raise him as a respectful, informed, and courageous supporter of the dignity and equality of all people, and a believer in the imperative to live sustainably with others in his natural world (p. 152).

The literature improved my understanding of feminist parenting exponentially. I only could find a limited amount of research studies on this topic. This definitely had an impact on the research I was able to include here, however the research studies I did find, were extremely helpful. Considering and exploring the research has helped me find different and unique knowledges within this topic and I am excited to go forward and add more voices to the literature with my own research, creating an even stronger 'motherline' (Green, 2009).

I am exploring the practice of feminist parenting and my focus is looking at the actual day to day practices that feminist parents use to raise children outside of those patriarchal parenting designs that can enable and perpetuate sexism, gender and sexual binaries, ageism, 
heterosexism, and performance of societal norms. My research is being guided by two related questions. (1) What are the current practices that feminist parents are utilizing to raise critically engaged, socially conscious children? And (2) Why they choose to be or why they feel it is important to be a feminist parent? 


\section{Chapter 4. Methodology}

I conducted qualitative research, as trying to use quantitative methods simply would not get the rich understanding and information I was seeking. I used narrative analysis (Padgett, 2008) as I wanted to get a deep understanding of politically conscious parenting and what strategies they use. I aimed to discover what their daily resistance looks like and the practices they find to be useful, but also why they are choosing to parent from a feminist informed lens. Also, drawing on Riessman (2005) it is important to utilize methods that are in contradiction of dominant sources of knowledge. Narrative inquiry and analysis does this by putting emphasis on the human reality and story.

It is important to move through narrative inquiry, to feminist research as I am a woman and I am writing about feminist parenting; Presser (2005) states, "feminist research begins with women's own perspectives and experiences" (p. 2067). It is important however, to embrace all female identified people in this statement, to not leave any story behind. As I mentioned earlier, historically voices and realities have been silenced, when we focus solely on biology. Therefore, to voyage through this journey of research, I needed to find a specific methodology that would connect well and support my theoretical framework of transfeminism. I found a methodology that significantly represents my framework and creates space for intersectionality to exist. I used intersectional narrative feminist research (Fraser \& MacDougall, 2016) to give opportunity for intersections of all people to be a part of this study.

In reviewing multiple sources about narrative inquiry, my impression is that it's aim is to illuminate voices of the subjugated and ostracized (Fraser \& MacDougall, 2016; Padgett, 2008; Presser, 2005; Reissman, 2005). Its intention is to disrupt and discard the understanding that dominant stories are considered the standard. This coincides with transfeminism, as well as the 
need to lift up alternative discourses like feminist parenting. As well, with this methodology, it gives participants the agency to "explor[e] subjective meanings and experiences that have been ignored or silenced in previous research, allowing for new insights and awareness into social processes" (Fraser \& MacDougall, 2016, p. 4). A central component of this research is linking the personal with the political, which is imperative in this study. Understanding the social conditions and norms, to then change or shape the way you parent is already being able to make that important link.

Another key theme with this methodology, along with other narrative forms of research is story telling (Fraser \& MacDougall, 2016; Riessman, 2005). There is a process of constructing a story, and a voice, and a reality that is true to narrative methodologies. This was my goal in this study, retrieving an insight into their lived realities and practices and the ideologies that stand behind them. My goal with utilizing this type of methodology is not to get a right answer, or one experience; it is however to create spaces of multiply situated knowledge and unique understandings of parenting.

Within the lens of intersectionality, it is important to understand my privilege as a white able-bodied, cisgender, woman that is in a privileged position as a researcher as I enter the sites of conversation with my participants. Appreciating the diversity and positionalities among the people interviewed, and the intersections of gender, class, sexuality, race, ability and age is crucial to embodying that intersectional gaze; as well as understanding how gender and sexuality influence how particular group members experience social issues. I will also be furthering my feminism by the frameworks of intersectionality (Fraser \& MacDougall, 2016) and transfeminism (Koyama, 2001). These advance the thought of who and what feminism represents and attempts to fill major gaps in the narrative of mothering. These approaches, along with 
critical feminism help us unpack the discourses that patriarchy has pounded on us for so long and appreciate the diversity of families, parents and women around us. We need to widen our perspectives when it comes to what constitutes a family (Mack-Canty \& Wright, 2004; Schmeiser, 2011) and also how we raise our children to interact with the world. Therefore, my belief is that intersectional narrative feminist research supported me in unsettling normative discourses and then also helped to rebuild stories.

A key element within narrative feminist research is linking the personal to the political (Fraser \& MacDougall, 2016) which is the constant stream that enlightened my work. This is an opportunity to relate personal stories to larger systemic issues. With this informing my work, it reinforced my understanding of the larger purpose for why these parents are parenting in a feminist informed way. Another principle within this study is informed by Brown and Strega (2015) who state that

Using flexible research designs, accessible language, and friendly interviewing or group facilitation styles, we can design research that provides opportunities to participate in research that (also) disrupts power relations and allows participants to present themselves as agentic people who had desires, dreams, and hopes for the future. (p. 247)

This helped to inform my research design, as well as my questions. My interviews were informal and encouraged a resistance of power structures, as they became more of a conversation. The women I interviewed were active participants and I received feedback from all of them that they very much enjoyed the conversations. In one particular situation, one of the participants actually said that the interview had empowered her to view her parenting as successful.

The people I interviewed were self-identified feminist parents that are raising/raised child(ren), as this is the community I am exploring. My recruitment asked that they were to be 
aged 18 years or older, which they all were, ranging in ages from 31 to 54 years old. I was also recruiting to people living in the Orangeville or Toronto area, as those are the two towns/cities that I am in most often, all my participants were from the Greater Toronto Area. I did not have any participants from Orangeville.

My recruiting technique was purposive sampling, as I do not have any ties to people in this community. I put up recruitment flyers at Ryerson University in Toronto and in the community centers in Orangeville.

My method was in-depth interviewing as it was the best way to get a grasp on peoples lived experiences and story-telling (Padgett, 2008). I think interviews were the best way to erect their own voices and realities. I do not want to just mine for information, I want it to be part of a co-construction of knowledge (Fraser \& MacDougall, 2016). I interviewed four self-identified feminist parents; the individual informal interviews lasted one to two hours, each. These interviews were audio-recorded so I was able to give my attention in full during the interview. I then transcribed the audio-recordings after the interviews, for the purpose of in-depth analysis.

To develop my findings and discussion chapters, I used thematic analysis (Riessman, 2005), as it focuses on bringing together the stories through themes, and really looking at the content of the information. The parents involved in my research are actively engaged in the strategies that they are discussing, therefore they are partaking in storytelling as praxis. This is seen as a form of social action, as "storytelling is a communicative practice that is embodied, situated and material, discursive, and open to legitimation and critique" (Riessman, 2005, p. 5). I used this approach to actually hear the voices behind feminist parenting and let them speak; this method worked incredibly well with the four narratives. As well, I utilized feminist theories, in which narrative is integral, and so is linking the personal to the political. These ideals grounded 
me, aiding in my use of thematic analysis as the content from the interviews was deeply imperative to fully understand every woman's perspective.

While linking the personal and the political throughout the whole process, from the stories to analyzing the data, and understanding the effects of social problems in ways that do not hyper individualize the people that experience them, I was closely connected to feminist narrative approaches. By continuing to unpack power relations, resist dominant discourses and engage in continual critical reflexivity, I am contributing to transformative anti-oppression and critical feminist theories. Most importantly, this methodology is "committed to doing (engaging, applying, addressing, intervening) not just thinking... and dedicated to addressing, not just understanding, social problems" (Fraser \& MacDougall, 2016, p. 8). 


\section{Chapter 5. Findings}

I sought all self-identified feminist parents in my recruitment; however, only womenidentified people answered and thus I had the opportunity to interview four wonderful women about their feminist parenting experiences. I will be using pseudonyms for each of the participants for confidentiality purposes. The women ranged in age from 31 to 54. I did ask in my demographic questions for how my participants identified with their race, sexuality and gender, to ensure an inclusive picture. I had two self-identified white women, London and Valerie and two self-identified Black, African women, Nneoma and Yejide. All women identified as being cissexual. London identified as queer, but the three other women identified as heterosexual. London, Valerie and Yejide shared that they had one child and Nneoma had three children. All of them identified as being single parents, as all were raising their children separate from the father, although the fathers still played a role in all of the children's' lives.

Due to the originality in each of the following woman's lives, I am going to separately introduce their feminist identity and how the world has brought them to a place of feminist parenting. Using thematic analysis, I then utilized their narratives to create underlying themes in three distinct categories; why they parent in a feminist informed way, what strategies they engage in with their children, and the outcomes of parenting this way.

\section{Feminist Identity}

Although this research is about the day to day things that feminist parents do and why they do them, there is a whole journey to feminist ideals that takes place before that, that I wanted to explore. So, I did ask the participants about their own feminist identity, to understand why they are motivated to parent from a feminist lens more fully. There were many overlapping answers, but each woman had their own narrative that I would like to share. 
Yejide identified herself as coming from a Black feminist lens and the specified it to an African Indigenous feminist perspective. She uprooted the popular notion that feminism is western based and tied to the ideas of the developing world and how colonization and white supremacy has created this lens and she discusses where she thinks it begins,

I think why there's that perception because of how, education structures - and this is postsecondary education because with elementary and secondary you don't get any kind of education around feminism, around women's contributions and we're even talking about white women here, you maybe get a snippet here or there...so in the post-secondary context there are some pockets of space where you can learn a little bit more about other forms of feminism...sometimes it reproduces those imbalances in terms of race, sexuality and disability, I would say although that's changing now, so I think that those are places I was able to explore it.

Yejide also discusses that her feminism is intersectional and tied to her indigeneity as it is bound up and "woven through the issues of colonization, race, gender, class". She shares that her feminism, "structures how I live and understand the world" which creates a grounding for her and how it interacts with others parts of her life, noting "it's fundamental to my career... it's very important in terms of my relationship with people". She uses her feminist ideals to disrupt thoughts around stereotypical roles, the damaging confines of femininity and masculinity and her historical roots; by sharing, "there are dominant ways of thinking about gender, masculinity and femininity which are really damaging to all of us, so feminism is so important to being a mom" You will see in the pages to come that Yejide uses her feminism to project attributes of love, acceptance and understanding to her child but also to give him a critical lens around oppression and power. 
London's expression of feminism voiced a need for an intersectional lens, but also an understanding that people only truly understand their own experiences; she says, "I like to speak to my own experiences as a woman, feminist fits with that and I think feminism should be intersectional". This intersectionality for her includes, "allying with other groups... [and] highlighting and recognizing oppressions exist and how to speak to them". She discussed the dominant scripted gender roles and how she and her daughter are trying to push back these rigid restraints on children's growth. Her daughter has discussed the idea of "using they and their pronouns but she is still toying with it...because she is sick of the girl and boys stuff, and she's just like, 'we're kids' "; it seems as though the pressure is already so much at just the age of nine years old. Her daughter has not decided on this at the time of writing and therefore that is why I am using the word 'daughter'. London is a blogger that shares her feminist views online, which is actually now being used, legally against her in the court system right now. Daily, however she focuses on her feminist ideals creating a beneficial environment for her daughter.

Valerie defined her feminist identity as it related to her critique of large systemic issues, like capitalism and racism. When examining the effects of inequality, she discusses, "I think it's important to recognize the ways that women are pigeoned impact the types of opportunities and chances that we have, which are identifiable as structures of inequality that are also tied into capitalism, patriarchy and racial oppression." Valerie lends her critique and analysis from an academic standpoint and you will see within the themes to follow that she finds it important to raise her daughter with a lens that is informed around issues of coloniality, diverse structures, inequalities and oppressions.

Nneoma stated her feminist belief as, "an individual who believes in the rights of every individual to equality of access, equality of opportunity and the equality of recognition under the 
law and in society." Nneoma discusses believing in equitable rights while having young children, although once separated from her abusive partner, is when feminism really started to architect a path for her, into advocacy, fighting for women's rights and utilizing feminist language and strengthening her feminist ideals with her growing children. She shared that, after the separation and the explosion of violence and me getting into VAW work, and then I became exposed to the language and...the movement... and the failure of the system to acknowledge women's worth and how offensive it was... and I would talk about how the world is structured and how disruptive it is...we could have really meaningful conversations about the media and how it represents women.

She shared that having conversations around these issues and exploring the social dysfunction of how the world is structured, it was easier for her to relay to her children how their personal story related to the political landscape. With raising both male and female-identifying children, she navigated a world where her feminism would be meaningful for all of her children and juxtapose the negative implications that can come with having an abusive man as a father figure.

Within all the interviews around feminist identity, there was a lot of discussion around intersectionality in terms of race, gender, class, ability, sexuality; as well as bringing in critiques of dominant systems and power relations. Ultimately the women identified feminism as a force that structures how they live, comprehend and approach the world around them. Most of them having an intimate relationship with feminism before becoming parents and therefore, it being a natural influence in their parenting. All of the women also coming from educated perspectives and many shared that their knowledge had been deepened and strengthened with their experiences of post-secondary education. Another experience that all the women had in common 
was being survivors of gender- based violence. This came through heavier in some interviews than others, but was present in all, this will be delved into deeper in the themes to come.

\section{Navigating the World}

All of these experiences influenced the women's feminist identities, but so did their experiences growing up. There is no one story here; each experience was very individual to that person. Valerie and Nneoma both grew up in single parent households after a parent died at a young age. London was adopted late into a two-parent, liberal family and Yejide was raised in a context where a specific ethnic group within Western Nigeria had a strong impact on her experiences growing up.

One thing that all of these women had in common around their own parents, was that they never put constraints on them or what they could do based on their gender. Yejide had an excellent analysis of this, by sharing,

So, I've never been told that I couldn't do something because I was a girl, but I've been implicitly treated that way... the impacts of colonization within that context, I see sexism playing itself out by women and men but from my mother for example, the matriarch of the family but in many ways, she has also been complicit and reproduced sexism, but coming from a colonial lens.

Although some of the women discussed that their parents had notions of what a "woman" should be, their parents were always supportive in what they chose to do. Nneoma talks about being raised by a single dad after her mother dying and shares that she had brothers and sisters and he treated them all equally within the home, as well as with his expectations for their careers; she discusses, "I talk about my dad being the first feminist that I can remember, he treated us all 
very equally". Nneoma does add however that because of and within society, "he did have particular worries about us based on our gender."

Valerie discussed her relationship with her mother as one that is nuanced, and complex. Growing up,

she didn't impose these kinds of physical ideas of what femininity had to be on me, which is interesting, but again she would have rigid understandings of how to define herself and her own self-worth as a woman which conflicts with my feminism in some ways...she has certain ideas of what it is to be successful and part of that for her includes having a partner, which she reads as male... she embodied a lot of the qualities that I think a strong female figure should have, but at times and I think as with any of us, our relationship with feminism and with our gender is complicated, so she still finds herself falling back into these rather oppressive tropes of what it means to be a women and a successful woman. One thing that Valerie does discuss is the fact that although she found her mother to be a strong woman, she never used the word feminist; while describing her mother, Valerie said, "she would never have described herself explicitly as a feminist".

An issue that was discussed by a few participants was the language around feminism, and how it wasn't really used in the houses that these women grew up in. Although some of the ideals may be described as, or linked to feminism, the language tying them together was absent. Some of the women talked deeper about this idea of feminism being a word that people do not want to associate with. For Nneoma, this came through a discussion around challenges of identifying and parenting as a feminist, she answered,

how society [sees feminism], it's such a dirty word and I know it hasn't stopped me, but its stopped a lot of people who are feminists, equal rights for everybody, but they just don't 
want to be associated with the word because of the brilliant marketing job the Men's Rights

Organizations have done to paint this filthy, horrific [picture] ... it's been a challenge to constantly say, 'oh no but I'm not that, no no, you misunderstand feminism'.

Just like these diverse women grew up in different social landscapes with various family backgrounds, their feminism embodies those differential experiences and their analysis varies based on their social locations and subject positions.

\section{Feminist Parenting}

The meat of this research is to uncover the practices of feminist parents and how they erect children that may be more socially engaged and critically conscious of the world around them. The journey to discover the feminist parenting experience has to get to the root of why. Why do these parents want to parent in a feminist informed way? Why is it important for them to identify as a feminist parent? Ultimately, why is this important for them to do when raising their children? What is also important, is how is this style of parenting impacting their children? What is the outcome, that they can see at this point in time, of feminist parenting? Therefore, I realized through the interviewing process that I was really asking three different questions; which gave me a much more enriched lens to explore these incredibly rich narratives.

I am going to break up the next section into the three different questions, why, what and how. I will outline the major themes that emanated from the narratives for each of the three sections.

Why parent from a feminist lens? Four major themes were raised during this discussion, these themes ran through each of the interviews like a flowing stream. 
Critical lens. The first main theme was to provide a critical lens to their children. While some of the reasons behind this were distinctive, this was the most common, most repeated theme that came from the interviews. Yejide described this very eloquently by saying,

It provides that critical lens, that entry point that that allows me to be able to then pass on that critical lens to him and ultimately to love who he is with an embracement of himself, knowing it's grounded in who he is, as opposed to a denial of self or else wanting to, because you know people, so many of us in in trying to survive, in needing to survive we internalize um so I just want him to know and to have an anchoring that one needs to have, to live a full and fulfilling life.

The critical lens acts as a defense, a critical analysis to have on social institutions and larger systemic forces. To be able to have this critical eye leads to being able to question things from a young age, which we will explore more in the next section.

There was a lot of discussion around push back from the community, outside institutions, and this was one of the reasons that integrating that critical lens was so important for these parents. In one example given by London she discusses the difference in the way she is perceived as a parent bringing her daughter to the Women's March, opposed to someone who takes their child to church on Sundays; she explained she is met with people that comment to her, 'oh what an interesting lifestyle' to which she explained, "it's weird that letting her know that she has rights is a lifestyle, [laughs] I just don't know how that makes sense...like how can it be so strange to be informed?" Giving their children a critical lens seemed to be embedded in their inspiration in almost every question that I asked.

Resistance. The second theme seemed like a bird's eye view to a resistance, a resistance or backlash that is happening from feminists, mostly those with a critical analysis that is 
embedded within intersectionality. This resistance and refusal to take part and engage with dominant ideologies was very present when it came to why these women were parenting from a feminist pedagogy. First, there was a resistance against participating within the very confining limitations of cisnormativity, heteronormativity, masculinity and femininity. When exploring masculinity, Yejide discussed that part of anchoring her son was "teaching him that...you can be this kind of boy, but this is what it does to people and this is what it does to you...[as well as] a more fluid understanding of gender." All the parents engaged in some discussion on how these severe restrictions are damaging to the children they are raising. Something that emerged from the interviews was that all the parents were wanting their children to be themselves, with no labels, no rigid restrictions.

Next, there was a lot of discussion on the lack of adequate education within schools and therefore they took a lot of the education into their own hands. Valerie actually took this further by choosing to switch her daughter to an alternative school, because they focus on experiential learning and her daughter not being interested with regular curriculum, "I think also possibly because of the way she has been brought up as a very politically engaged citizen, she has a very hard time getting along with students in her class, she'll call them out sometimes." Valerie has hope that this alternative school will have like-minded people for her daughter to engage with. A few other reasons that this school was chosen was because they talk a lot about justice, they have a policy for gender non-conforming children, and they also have a decolonizing analysis based on a dress code asking youth to not wear racist sports team logos because indigenous activists have made it clear that it is racist. One of the other schools that Valerie and her child looked at had a separated gender policy for math and science classes, Valerie shared she disagreed with this, 
I feel like that approach, while I understand where it is coming from, I feel like in the long run reinforces reinforces those tendancies or raises those women to only be confident within the company of women, along with the problematic division of genders and the factoring in of gender as a critical component of the learning process, which I'm critical of.

I look at this choice that Valerie and her daughter made as a refusal to occupy spaces that are not focused on justice, that continue to reproduce dominant ideology and colonized minds. Yejide also discusses the impacts of educational institutions, "In his school, I don't hear kids say 'that's so gay' but they do have an understanding of what normal is and it gets reproduced in the books, in the curriculum, by the teachers, by the principal."

Lastly, resistance against media which can be difficult; however, it is tying in that first theme of creating a critical analysis. There are many examples within the different narratives of an attempt at resisting mainstream media, but also at constantly critiquing it and having discussion around it. Yejide included media as a meaningful social agent in kids' lives while they are growing up. She examines,

if you think about these institutions, what are the messages that the kids are getting from the media, from schools, from dominant religion... so we have to go to those institutions and have conversations about what's happening in those institutions because otherwise [children] take them in as the norm, like Disney. I hate Disney (laughter). Because it reproduces and validates very hegemonic ideas around, gender, race, class, ability [and] sexuality.

We will discuss this more in the following sections. 
Always watching. The next theme, and this also was illuminated throughout the pages of transcriptions and came alive in the conversations with these women is the fact that their children are always watching and learning from them. This fact contributed even more to these parents taking action whether it be around discussing their own bodies, or buying lunch for someone experiencing homelessness, or dividing household chores equally or speaking out against harmful language on the street, or just giving you that extra energy to go out and fight the patriarchy for one more day. London spoke about, "now that I know that she's watching, I'll speak up more in general." Another issue that Yejide brought up was trying not to pass on to her son her feelings around the police. Explaining that although she is a black woman and is taken up in the "racist, sexist, stereotype of the angry black woman" there is also a way that black men are perceived by police, which is usually aggressive. She shared,

I say to myself all the time, you're going to have to change how you're approaching this, because even when I see police I think, oh [sighing] and I know he sees me and I have to change that because what that could translate to in terms of his actions could be a bad thing. So, one of the things that I'm always thinking about is, whatever I'm doing, I'm always being watched, there's these little eyes on me, these little eyes that are watching me. It seemed as though having those eyes following you, was that reminder to keep on going, but also, the one that held you accountable.

Survivors of violence. The last theme that again, came through all of the pages is the fact that every woman I interviewed had experienced gender-based violence, in most cases from the father of the child(ren). That journey had amplified their desire to parent from a feminist lens, due to the possible negative implications of having a father figure that exudes misogyny and acts violent toward women. One example given by Nneoma was "it was important for me to create a 
space for my son in particular to understand that it was not okay to treat women the way his father treated me." Valerie also discussed the extra work for her that having this kind of partner creates,

I had an abusive, misogynist partner, who is the father of my daughter. That is a constant in our lives and so I'm always trying to reinforce my feminist ideals, but not necessarily in that very overt way, but just trying to maintain a balance knowing that whether or not it's kind of very outward that he embodies those ideals. He definitely sees women as subservient and embodies the ideas of patriarchy. He sees women in subservient places especially when they become women, so that is always at the forefront, especially now because that she's coming into womanhood, how to manage that and mitigate that, so that's definitely one place that it confirmed my parenting.

It shows that having someone with these ideals in the other parenting role can further the work for the feminist parent and this definitely contributes to why these women parent with a feminist lens.

What practices do feminist parents utilize? It was difficult to narrow down the main themes within this section as this is the bulk of the study, but I was able to pull out five important themes. These five themes were embedded and intertwined in every narrative.

Exposure. The first theme that was extremely magnified in every narrative was exposure. Every parent that I conversed with discussed exposing their child to inclusive lifestyles and identities and relationships, was integral to their feminist parenting. One of the motivations behind exposure being used as a tool, is to normalize ways of being that are now looked at as non-normative or deviant. London discusses that having conversations around certain topics is so easy because they know so many different people with so many different identities. They have 
friends that identify as queer and her daughter has a friend that just transitioned, therefore she has been given many different experiences. London realizes the importance of exposure in learning about oppression, and also empathy and says,

we're really lucky though because we do know a lot of people and I think it really is about putting a face to that experience... I don't think she sees any aspect of sexuality as deviant. It's never really been an issue because we've had examples of all sorts of families, situations and relationships in our life.

Valerie also discusses that if she does not have an example within her circle of friends, she will “talk about other people's experiences and expose her to other ways of being, that either play with gender or resist against those norms entirely, she's exposed to some artists that do that all the time."

Another way that all of the parents I interviewed seemed to educate children and expose them to other people and diverse life situations is through the use of books. Every parent talked about books as excellent resources, for body image, consent, different abilities, women's contributions and many more topics. Books seemed to be the constant go-to for all the parents I interviewed as a way to expose children to more stories and different lives.

Fostering dialogue and questioning. The second theme that was congruent throughout the distinct narratives was "fostering an environment that is open to debate and discussion" (Valerie). Each parent made this point, making it a clear, fundamental practice of feminist parenting. Promoting constant dialogue and conversation was very important to all of the parents to engage with their children on many topics as well as topics surrounding social justice. London shared an experience that she had, 
I was watching Fresh Prince with her and I was like, 'Yes! Fresh Prince was one of the first black families on television' and she [said], 'Yeah, but I hate how they're talking about women' and I was like oh yeah, now this is a great conversation about intersectionality.

There was a way in which this theme was interlaced with every other theme, as it seemed to be the utmost important to creating an open relationship with the child.

Another aspect that resulted from having that comfort of open dialogue was the ability of the child to push back, or challenge the parent on certain issues. Every parent discussed that their children felt comfortable enough to call the parents out on certain things. One example that Yejide gave was she was out shopping with her son and was buying a gift bag for a young girl and said that she had said that they needed to find a girly bag and her son responded with, "Mommy, it's not about a girl bag, there's no such things as girly or boy bags, they're just bags so pick whatever bag you want." Another example of this was when Nneoma made a comment about her daughter in a certain dress and, "she said 'you're slut shaming me mother' and I thought holy the fuck, I am, so I took it back." Even when the parents may let down their critical eye, there are many instances of the children reminding them of what they have been preaching to them.

This idea relates to power-sharing, which is a sub theme to this consistent dialogue and negotiation. All of the parents agreed that power-sharing is a tool that they use, although all said it has its limitations. They all said there were times where they would have to discuss that they couldn't compromise on something and that they were the parent and needed to make the rule. They did all find power-sharing to have its benefits however, whether it was to encourage autonomy by letting a five-year-old make the decision to be a vegetarian, like Nneoma did. Or 
we can consider Yejide's contribution, where she discusses the importance of power-sharing, "[he needs] to know that his voice, his feelings and his needs and the way he sees things are important, but if I'm dictating all the time then he's not going to get that message." She also adds to this analysis by discussing the significance of power-sharing specifically with a boy, "because again there's all these messages that what it means to be a boy or a man is to dominate, to have control, to have power, for only you have it. So, negotiating with him is very important." What she is discussing is profound, she is showing that modeling power as something that is to be shared, is critically imperative to learn, especially for men in this society.

To have a better understanding of the significance of constant communication and powersharing in feminist parenting, read what Nneoma discussed in her narrative. She said,

Having the space to have your opinions and hold them, discuss them, wrestle with them and not having someone say to you, because I said so, shut up, not in my house and it was difficult because sometimes it's convenient to say 'because I said so' but it was just so much more interesting, it was a much more interesting experience as parent, listening to my children's opinions about the world than - because I knew what I thought and they're different people so they brought different perspectives.

I thought this was an excellent way of looking at children as people, having their own thoughts and understanding that they are living their own journeys as well. This is a good concluding thought to the theme of open communication and comfortability of challenging a parent.

Never assuming identity. The third theme that was woven through the narratives was one of acceptance and not assuming any one identity of the children. This was also seen as a resistance toward dominant ideals and understandings of people, limited by certain oppressive 
lenses. As London says, her feminist parenting has allowed her daughter to disrupt the norms of cisnormativity and go beyond the gender scripts. There was also this openness and acceptance all throughout the narratives, one example from Valerie reads,

with my mom, she'll [say to her], 'one day when you're married with your husband', and I'll be like 'Mom!' [laughter] and then I'll be like, 'or your lesbian partner or your nonpartner or your polyamory relationship' um so now [my child] kind of laughs, but I think she also kind of knows that that's accepted.

This was also found in Nneoma's narrative, where she examines the fact that you do all this work at home, and yet when you send your children to school, all of that work starts to unravel; as they are taken back into the world of strict labels. She shared her frustration around this revealing that as soon as they got home from school, she would have to start building all that grounding knowledge again. Nneoma explains, “it's like they leave my house... they get to school and then all the work I've done starts getting undone and then they come home and I have to redo it, and strengthen it, and send them out again"

The school seemed to be large blockade in the consumption of feminist knowledges; not only a blockade, but a deterrent, attempting to take away all of the work that the parents had begun at home. The school system in many aspects is a setting where oppressive learning takes place. Yejide discusses "my son has had experiences around race and racism with the principal and his teacher". These interactions have caused Yejide to enter this blatant site of oppression to have conversations with the teacher and principal, to educate them on these matters. She shares her cognitive dissonance around this by pointing out, "how often does that happen, black women are educating white women...black people are educating white people about racism and don't get paid for that work." Therefore, she realizes the need for her to be in the school, for her son's 
sake, yet there is this imbalance of power and conversation around worth of knowledge and work happening.

Nneoma shares another example, My daughters went to all girl's schools, and I sent them there because I had this expectation that they would be surrounded by women, who if not all but, most of them, would be feminists like me. But it was a real shock to learn that there is a lot of traditional, very traditional, lots of women that still admire that traditional sense of what it is to be a woman, in these schools, teaching the women of tomorrow, sort of ancient fucking history of what it is to be a woman. That was a shocker...so the school became site locations where it was almost as if we were fighting on opposite ends.

So, although these parents are in constant teaching mode with their children, they are also continually resisting against oppressive structures, like educational institutions, seen in the examples above.

Body reclamation. The fourth theme that rose from these rich narratives, was one of body reclamation. This is a broad concept, with sub themes of race, ability, bodily autonomy and femininity being seen as powerful. When I asked a question around body image, I received very diverse answers that stemmed from the lived experiences of these four women. From both London and Valerie, body image was a concept that they had long discussed with their daughters, due to the fact that they had both struggled with this concept as women. What came out of these conversations was a few things, one being body positivity. Both women discussed that if their daughters do overhear them say something negative about their own bodies, they will correct it right away. Valerie shared that, 
when I do notice that I have said something in front of her or within earshot, I do try to correct it and be like, 'you know this is a particular thing that I've struggled with, not that I've struggled with my body but I struggled with the way that I value my body and it's not something I want you to have'.

Both women discussed the importance of not body shaming. London had reached out to a friend, who runs a body positivity organization and discussed the need of talking about the body in a way that considers what your body has done for you. Both of these women put in a lot of work so that their daughters could think positively of their bodies.

Something that all of these women discussed is the notion that your body is your own. All of them having young children, the topics around consent happened often and using the right anatomical terms to teach and talk about one's body was integral to giving their children the language and ability to articulate to others, around their body and their space. London explained, "I have experience with gender-based violence myself, so in my parenting I want to be able to prepare her for such things, and the language to articulate if anything has happened to her." In this conversation, we also had discourse around bodily autonomy, which all the women found to be incredibly vital in the lives of their children. All of the mothers engaged in making sure that their children knew that they had control over their own body and no one else's. Yejide shared that her son, "knows that he has a right to his body, he has a right to not be touched or hurt and he feels good about that." This contributes to a sense of pride, agency and body reclamation. Valerie also discussed that her daughter knows "full well that her body is her body and anybody coming close to it, it needs to be sanctioned".

When conversing with the women, there was sense of frustration from most of the women around the ideas of body image and it still being something that takes hold of their lives, 
as grown women that identify as feminists. There was a lot of struggle around this issue, and yet two of the mothers brought up topics through this conversation that critically analysed and strengthened it even further. Yejide brought up the conversation of ableism and how physically different and differently abled bodies do not even get raised in the conversation around body image and how this breeds ableist knowledge and conversations. I thanked her for this contribution as I myself, as a privileged able-bodied person had overlooked this conversation, within this question. She strengthened this conversation by adding,

I guess this is a very ableist conversation we're having because thinking about children and having different bodies... and I'm thinking that even the book that I have, they don't have any of the children with physical disabilities... it was diverse racially but it wasn't diverse in terms of abilities. All the children had two legs, two arms, they were all standing up, so it is about body image but again, I think being able-bodied with that privilege, you don't even think about it...so it's interesting, oppressions get reproduced and sometimes they get overlooked, [and] it is about body image.

The other topic that was unearthed through this discussion on body image was that of race. Nneoma addressed the need as a black feminist mother, to give her black children confidence in their black skin; she shared,

I always talked about how beautiful their skin was, the skin that they're in, so being black was important on many levels but primarily they're black girls in predominantly an allwhite girls school...so it was important for me that they never lost a sense of pride for the skin that they were in.

Nneoma also discussed the importance of this as it related to media and the lack of representation for black women. These important aspects of body image strengthen and deepen the discussion 
on body positivity and reclamation, because depending on your subject location and the certain power imbalances that land on your body, all of these topics are essential to understanding and growth.

Utilizing community. The last theme is one that every parent cited, the use of a community. This was more of a strategy for the actual parents to utilize themselves. It came through in different parts of all the conversations, countless times. All of the mothers talked about having groups of friends, like-minded people and a community to help with their own challenges around parenting. The mothers employed the use of these friendships to help keep themselves balanced. All of the mothers went through separations from the fathers of the children and utilized their close communities for support. Nneoma shared, "I talk about keeping company of other survivors is the best thing that I've done for myself." Valerie also discussed how having friends has supported her,

[my child] came home and asked why the men's rights position wasn't valid, my best friend, also from school was with me at the time, so we had a long discussion [with her] about that and at the time, she had just come home from her father's, so I could tell where this was coming from"

A lot was conversed around the fact that these women surrounded themselves with like-minded people, which aided them in their feminist parenting. I found this to be a constant theme of these narratives and one that gave these women reinforcements and a cornerstone.

Outcomes of feminist parenting. Although many of these children are still youth, many attributes are starting to uncover themselves and I am going to bare one main theme that unifies the characteristics these parents shared with me. Due to the feminist lens and the practices that these feminist parents employ, many qualities within this broad theme can be attributed to a 
foundational feminist knowledge. The theme that I am going to identify is something that was noted as being found within the characters of all of these children. The all-encompassing theme is that all of these children have a critical lens and an ability to question. They have a foundational knowledge of power and oppression and an understanding of how structures and people work and with some, an agency to challenge.

I am going to discuss London and her daughter. London revealed that when she and her daughter are walking, they will stop at posters or ads on the street, and London will ask her daughter questions about the images, like how many women do you see in this ad? How are the women being used? How many white faces do you see? This strategy along with many others that we have thoroughly discussed in the last section, have made London's daughter aware. One example of her daughter's awareness, who is under ten years of age, was exemplified on an outing for pizza. As they were out for pizza, the man behind the counter kept making comments about both the daughters' and London's appearance, London shared, "I just ignored it, I wasn't really in the mood, so I was just like let's get our pizza and then we left and the [her daughter] said, 'that was good food, but that cat calling wasn't appreciated'." So just having the ability to pick up on certain types of discussion as problematic as opposed to a compliment is strengthening that critical lens and ability to challenge patriarchal notions. London's daughter also had a friend that transitioned recently, and is now a girl and an incident happened at Comic Con where that friend's wig fell off. London explained that,

"she was really upset, because it is really important for her to pass and my nephew was like, 'why is she making such a big deal about her wig?' and [London's daughter] said, 'it's a big deal for her, that's the way she wants to look and if you don't understand, we can talk about it later"”. 
These are just two examples of this young child that has a much deeper understanding of people and of oppression than a lot of grown people.

The next example I am going to share is one from Yejide and her son, who is under ten. He said something that is very nuanced to his mom, he said, "you know mommy, if white people don't like black people, then you know what we should do, we should turn white and tell them to respect us and love us and then go back to being black". Yejide's reflection of this was,

And what I found so powerful is what he said, he understood power because what he was saying was they're not listening to us in our black skin and so we're going to turn white and we're going to make them listen, but you know what, we like being black, so we're going to go back and I just thought wow... I just think okay, so that's a validation I am doing something right.

This understanding of power and race relations and yet also a love for himself and who he is, at a young age is profound. When Yejide shared this story with me, I was absolutely blown away and very struck that at such a young age, he already knows the detrimental reach of white dominance and supremacy.

There are many other stories that I could share, from critiquing virginity discourses to advocating for women's recognition within the school system, to standing up for people at recess, to having an understanding of the intersectionalities of lived identities. There are countless times in which each of these children have illustrated and embodied the teachings of these feminist parents and I wish I could share them all with you; but it is a demonstration that socially engaged, critically conscious parenting can be done, with true results. Valerie said something very powerful in our interview and I want to use this excerpt from our conversation as an illumination of all the themes bringing everything together. She remarked, 
I think just giving your children a lot of experiences...we experience culture in a way that embraces all gender identities and all sexualities and I think that exposure for her, it's starting to normalize what is otherwise deemed through popular media, as not normal. Even if they're accommodated there, it's on the basis of being a deviation of the norm and by her experiencing that in her everyday life, I think she gets around that in a lot of ways or it does some of the work. So, I think that's really important and then when she comes back and all of those things are already normalized for her, she's also able to decode it simply and quickly to pick up on moments of systemic oppression and inequality in a way that she once hadn't been able to, had she not been exposed to this as normal she [may] look at these accommodation practices and tokenism and think that they're fine. But because she's already seen the other side of that, she's able to point out sometimes when those things are wrong and I hope that continues going forward because ultimately you know, feminism will be for her whatever she defines it to be. So, she just has to have the tools to be able to assess in any given moment how the constructs of gender and sexuality and other forms of oppression on identity is infringed upon her and the people she knows and loves around her and the world in general.

From learning about the originality of these four women within their diverse understandings of feminism to how they have navigated the world, we can appreciate the multifaceted narratives that they all shared. We also can recognize that there were common themes that illuminated the transcriptions of their interviews surrounding feminist parenting.

When discussing why they choose to parent from a feminist lens, the themes that emerged were; cultivating a critical lens for their children, resisting dominant confines and ideologies of what it means to be a woman or a man., and understanding that their children were 
always watching and learning from them. It also is important to note that every woman I interviewed was a survivor of violence; this unexpectedly came through in each of the interviews.

I then examined the practices that these parents engage in when raising their children and found five themes. I first found that exposure to inclusive identities and lifestyles was integral to their parenting. What then developed was fostering dialogue and questioning with their children, which composed of power-sharing. Next, there was always an openness of identity, without assumption, from all of the parents. Body reclamation and utilizing community were the last two themes within the 'what' category.

For the final category, we derived the outcomes of the style of parenting. The shining bright outcome was the fact that these children did have a developing critical lens that grounded them and gave them the confidence to question. This was the wonderful reason that all of the parents engaged in feminist parenting. 


\section{Chapter 6. Discussion}

I went into this research urging to uncover practices and strategies that feminist parents utilize in raising critically informed children. I came out the other side having a very valuable, rich understanding of four women's journey through feminism and how that translates into parenting their children. I was able to unearth underlying reasons why these parents decided it was important to parent in a feminist informed way, to provide their children a critical lens to view society, power and structures, as well as to navigate through oppressive institutions. They also utilize this style of parenting as a resistance against normative and dominant ideologies and a location to carve out space for their children to architect themselves, free of dominant restrictions. Additionally, they care to parent this way because someone is constantly learning from them and watching them and they lead by example. Lastly, and this one was unexpected, it was not my recruitment style that every woman I interviewed would be a survivor of gendered violence, it just seemed to happen that way. I think this says a lot and needs to be researched further. All of the women that I conversed with, that shared their narrative with me were brilliantly educated, profoundly smart and informed women; I look up to all of them with immense respect and admiration. These women were also targets of violence and then, became these powerful feminist parents that were exceptional in their own ways. It would be interesting to see further research into the relationship of survivorship and feminist parenting.

In addition to why these parents chose to parent with a feminist lens, they also shared what their strategies and practices were to raise children that were politically engaged and critically aware. The main themes that were uncovered were exposure, open communication and power-sharing, not assuming any identities and resisting dominant labels, body reclamation, and utilizing networks of support and community. These were the overarching themes that came 
through in every narrative; if I had more space and this was a larger project I would definitely add in other themes that emerged from the narratives. I think this research would do well on a larger platform.

Furthermore, I was unbelievably fortunate to receive narratives around how this type of parenting benefited the children. None of my questions actually asked for stories or examples of how the children demonstrate this learned pedagogy or feminist framework, and yet I got many. I think I had well written interview questions and I used follow up questions to further some conversations. All of the women told these stories very organically, and with a lot of pride. I was so privileged to be able to hear tales of how the children have gained a critical lens and how they are comfortable challenging both their parents and the dominant discourses they've seen through the media or outside institutions. Cultivating a critical lens has shown to be imperative to having a deep understanding of social structures, and these children are developing theirs, with the support of their parents.

Ultimately, due to the absolute honest and complex narratives I was given the opportunity to hear, I was able to delve deeper than I could have imagined and discover and explore many themes around feminist parenting. Themes and topics that were illuminated through my research, were actually missing from the theoretical review of this subject. I was given the profound experience to be brought into the worlds of these four outstanding women and mothers, and I could not be more grateful. It is due to their lives that there will be more critically informed and socially engaged adults in the world.

Utilizing a transfeminist lens while journeying through this study, gave me sturdy pillars to stand on. Due to this lens, the priority was holding space for all identities. I furthered my own feminism throughout this process. As a white, able-bodied, cisgendered woman, that is also not a 
parent, I had to continue to challenge and advance my own understandings of feminism, motherhood and parenting through this process. I learned many things from this study, I think one of those many things is that feminism is strong and inclusive and it can work for everyone. I discussed in Chapter Two that an ideal that transfeminism puts forth is that we need to disrupt the fact that femininity is secondary and subsidiary to masculinity (Serano, 2007). This was brought up in this study frequently, along with the idea that gender and sexuality should be seen as more fluid, and binary standards should be decamped. The ideas here focus on leaving more than just a singular way to be, or constricting boxes to fit in, and instead being in many ways, which aligns with transfeminism.

Another way that transfeminism supported me in exploring this study was the fact that the magnifying glass was not on the individual, it was on the larger systemic forces that these parents were resisting. Although the rich narratives are filled with these women's lives, values and practices, the reasons they are engaged in this parenting style is a result of the negative implications and blatant harm of dominant discourses of patriarchy. Critical reflexivity, which is a part of both transfeminism and an anti-oppressive perspective, reinforced and braced me in this journey. I was constantly engaging in reflexivity before entering homes, during my interviews and especially when exploring my findings. Understanding certain power relations, linked to the way my white body takes up space, as well as reflecting on my socio-economic status, and privilege I carry as a Master's student and the way power is perceived through these spaces, was instrumental in reflexivity in this research. As well, examining certain relationships between myself and the mothers that participated had to be an active muscle I constantly utilized, as I am not a parent at this time which highlighted their expertise and continually put me in the position of learner. Although there were many collaborations with myself and the mothers, while in 
conversations to pull out themes. These interrelations all depended on me utilizing that transfeminist lens, looking well beyond how certain people and identities are essentialized, in terms of race, sexuality, gender, ability, along with the identity of mother.

In Chapter Three, I discussed the literature that I had found within the research of feminist parenting. The first issue that I examined was motherhood. This is interesting because most of the research I found was on feminist mothering. I wanted to interview all and any type of parent in this research, but I only received interest from mothers. The mothers I did interview however, really resisted against or did not identify within the confines of what Green (2009) called the 'ideal mother.' This was an aim of using transfeminism, to reach narratives that have been historically silenced or left out. This study gave voice to black mothers, queer mothers, single mothers, low-income mothers, working and in-school mothers. The participants in this study really disrupted these notions of an ideal mother having to fit in a box, be in the household and at the same time being a perfect wife (Green, 2009). It was very refreshing to hear of women that made parenting and feminism their own. What I have discovered in this process is every one of these women identified with parenting and feminism differently and had their own definitions. This complies with transfeminism, in the way that every person should be able to write and live their own story, along with their own determination of feminism and the fluidity of how that identity changes.

The second theme that emerged from the literature review was that feminist parenting is a political act (Green, 2009, 2015; Schmeiser, 2011; White, 2006; Wu, 2004). By framing it as a political act, it reiterates that feminism is about linking the personal and the political (Fraser \& MacDougall, 2016; Koyama, 2001). I saw this repeatedly in my study. Many of the participants discussed this ideal being a part of their own feminism. Critical discussion and creating dialogue 
around oppressions and privileges can be seen as a political act (White, 2006). This is something that was very evident throughout my study and became its own theme. Having open discussions around power relations and the way systems in society operate was demonstrated heavily within the narratives of these four women. Lastly, to add to the theme of political action, a few of the mothers I interviewed also engaged in taking their children to protests and demonstrations, reiterating just how much this theme was found throughout my study.

The third theme that was mentioned in the literature review that coincides with my own findings is power-sharing and open communication (Green, 2006; Mack-County \& Wright, 2004; Ott, 2011) by creating trusting relationships. This is seen through this study as another sub theme, with children getting more autonomy and agency. This disrupts normative approaches that children are powerless in the relationship with their parent. The importance of power-sharing was discussed by Yejide when she talks about modeling the negotiation of power with her son. The literature also discusses that critical thinking (Green, 2006; May, 2011; White, 2006) gets children thinking and assessing structures, situations, oppressions and injustices, which may be another reason that these children seem to have a critical lens as an outcome of feminist parenting.

In the literature, a theme that I illustrated was collective parenting (Green, 2015; hooks, 2015; Ott, 2011). We saw parts of this within this study, when the parents all discussed having and engaging with a community. I find that this is really important, because this was something I was unfamiliar with and the literature introduced me to this concept. I did not ask a question relating specifically to this concept, and yet in every interview, these women discussed the importance of having a community of like-minded people around them. I do not think there is 
enough research or enough known on this topic of collective parenting or the impacts of it, but I was happy to see this association between the literature and my study.

The last theme that I outlined in my literature review came mainly from White (2006), hooks (2015) and a few other sources, in which they discuss the importance of fathers to annihilate stereotypical gender roles in many ways. I could not find this information in my study, likely because all the women I interviewed were no longer with the fathers of their children. Further, in every example in this study, the father actually had a negative view of feminism and feminist parenting, as told to me by the mothers. Due to the fact that I did not have the opportunity to interview any self-identified fathers and given the responses from the women I did interview, it is not surprising that I did not discover knowledge in this area in my work. I do find it disappointing that locating fathers within feminist parenting spaces was left out of this research, based on the lack of interest and participants for this study, as I do agree with much of the literature surrounding the monumental impacts of fathers or male identifying people to confront and disregard normative discourses. I do hope that there are feminist fathers out there, as it saddens me that I was not even able to find one. There is a need for more research to capture these fathers and parents, because I do believe it is imperative for change.

Conclusively I found many ties with the literature and my own study. Although feminism is something everyone defines for themselves, there are a lot of common themes that run through many of these studies. I was happy to see that my study confirmed many of the large themes that were pulled from diverse research studies. I think my study expanded the research by utilizing transfeminism as a theoretical framework and including questions about gender, sexuality, and oppressions. I think my study also expanded the research by introducing the reality that all women involved in this study were survivors of violence. I think this raises questions and is 
something that needs to be explored more and I think further research may help to answer what this means about survivorship and power relations.

\section{Strengths}

The most prevalent strength in this research was the women I interviewed. I had a tremendously enjoyable time having honest, and open conversations with all of these women and listening to their perspectives. The reason I was able to get so much deep information is due to the fact that I did interviews. Utilizing interviews that focused on narrative was an enormous strength in this study, my shortest interview was one hour and ten minutes and my longest was just over two hours. These women gave me the time to really get to know their lived experiences and their journey with feminist parenting. I believe another strength in this study was having all women as participants, as well as all survivors of violence, this gave me a very unique view and brought out different themes that I hadn't accounted for; so, I was very thankful for this. Another strength was utilizing my theoretical framework and methodology to develop questions that really created meaningful conversations and cultivated reflection. I got positive feedback from all of my participants throughout and at the end of the interviews, around the questions I was asking.

\section{Limitations}

There are certain limitations within this study. The first limitation is also a strength; my questions, as well as the length of the interviews, cultured so much data. I am labelling this as a limitation because I just did not have enough space for the size of this MRP to utilize it all. This disappoints me, as the information I was given was so rich and nuanced and delved into so many different issues that I am disheartened that I cannot use it all within this platform. I wrote in the strengths section, that I was given the unique perspective of mothers, however this is also a 
limitation. I wasn't able to recruit any male identifying people, any trans identifying parents or any same sex parents raising children, therefore, this research is missing information. I was raised by a same sex couple, however one of those people has since transitioned to a male identifying person and therefore I recognize the deep need for inclusivity and representation. In my recruitment, I was very open in having all identities engage with this research, however that is not how it happened. If I could take this research further, I would definitely want the addition of the queer and trans community and so this is definitely a large limitation in this study. Furthermore, that limitation continues into the fact that the only people represented in this study are the people that took part and therefore these narratives are true of their lived experiences and social locations, which were all very diverse, however it only encompasses these women.

The final limitation that I am going to discuss is just the smallness of the study. I would love the opportunity for this to be a larger study, to get more perspectives and include the voices of those that aren't being represented. This limitation is due to the restrictive nature of the Master's MRP. However, within the confines of the MRP structure, I do believe that I was able to unearth a strong study surrounding feminist parenting.

\section{Implications}

One of the questions I asked while interviewing my participants was how they think that their feminist parenting has influenced or impacted their children. I have discussed at length how beneficial feminist parenting is, and the crucial impact it has on the child(ren). One answer in particular, validated this whole research experience. Nneoma has three children in their twenties and answered immediately with, "I think it saved their lives." She went on to describe why she thought this and I am glad there was a recording of the rest of her answer, because that introductory statement was astounding and striking. Then the more interviews I did and the more 
I heard about the strengths and importance of feminist parenting, the more I came back to that answer. This way of thinking, the anti-oppressive pedagogy that grounded much of the feminist ideology I was listening to from these women, is crucial. This understanding of the world, of power imbalances, social structures, systemic oppression and discrimination, intersectionality, and dominant ideologies and constructs is meaningful in itself. To then have a critical analysis on ways to dismantle it and resist the dogma that spreads from large oppressive forces like white supremacy, colonialism, racism, heteronormativity, cisnormativity, ableism, classism and others is essential for social change and views on social justice and equity. This type of parenting enables that in the children that are being given it as foundational knowledge. As well, it is important to contextualize this in the landscape of our world today. This kind of thinking and understanding can literally save people's lives. We need to remember that people are dying based on systemic oppressions and dominant ideologies, this type of thinking can simply change the world.

As seen above, the diverse feminist ideologies that frame anti-oppressive and critical thinking, also situate and sustain the practice of feminist parenting. It is important to understand that the ideals and values lay the foundation to the actual act of feminist parenting. The actual act, are these parents engaging in praxis; whereby they are utilizing the knowledge and practicing it. When we discuss the importance of how our thoughts and beliefs influence our practice, and the absolute significance of practicing what we learn and discuss with others, it is imperative to see feminist parenting as a distinguished illustration of this.

As anti-oppressive (AOP) social workers, we learn all of these theories and frameworks and the question always is, but how do I put this into practice? It was illuminated above that these women, these parents are doing just that. They are utilizing their knowledge and they are 
transforming it into parenting skills. I think we, as social workers, as advocates and activists, could learn a lot from this parenting style and the ways the implement theory into their lives. There were many significant take-aways of this study, but I think one that would be beneficial to social work in particular, is the concept of practice and applying theory. Observing and appreciating the ways in which the women located in the pages above, walk through life, living in a way where their interactions embellish and reiterate their values. Knowing what theoretical perspective or lens a person identifies with, by how they live their life, is an aspiration for me, as a social worker. I hope that with my knowledge and education, as well as my lived experience I am able to live my life as an advocate and ally, in pursuit of, not only social justice, but equity and social transformation. My practice, professionally and personally has definitely been changed by this study and I hope it ignites a change in others too.

Although I am privileged to have the educational grounding I have accumulated, I have also tackled many things along the way. I am in social work because of the injustices I have seen and felt and the ongoing harm that is done to so many communities, myself identifying within some of those communities. However, in many aspects, I am a person that drips privilege and therefore, people may not see the struggles I've had or growth I've gone through, but they will see the affects. It is my aim to utilize what I've been given and shine through my practice. I want people to know what I believe, in the way that I act. I want to embody my beliefs. As helpful AOP was to my journey, I did need to further my exploration of power.

AOP social work is imparting these same fundamental teachings, which is excellent. However, it needs to go further, AOP needs to be embedded with more critical analyses like transfeminism, anti-black racism, and anti-native racism. The perspectives that were shared with me were influenced by all of these philosophies and they strengthened the foundational AOP 
model. Although AOP could be reinforced, I think it needs to be dispersed more, to more people, to more parents. The women that I interviewed had all done post-graduate studying, mostly in social sciences (social work, sociology and gender studies), so they came from an educated perspective; however, their lived experiences and advocacy work enhanced that knowledge. My hope is that we can offer this knowledge to more people, whether that be through social work occupied avenues, like Children's Aid Society or shelters or other places where social workers may interact with parents and children. I think this is important for tsunami of reason, may outlined in the sections above. 


\section{Chapter 7: Conclusion}

In this study, I explored the practice of feminist parenting and my focus was wanting to look at the actual strategies and practices that feminist parents utilize to raise children outside of patriarchal parenting designs. These are designs that can enable and perpetuate sexism, gender and sexual binaries, ageism, heterosexism, and performance of societal norms. My research was guided by two related questions. (1) What are the current practices that feminist parents are utilizing to raise critically engaged, socially conscious children? And (2) Why they choose to be or why they feel it is important to be a feminist parent?

I was able to explore these questions with the four women I interviewed and find many congruent themes in both of these answers, discussed at length throughout the findings and discussion sections. I was also able to uncover potential outcomes of feminist parenting, by being given stories of their children and how they demonstrate what they have been taught. Again, these women were kind enough to embrace me and let me step into their lives and hear their perspectives for a short time and I am so thankful for their generosity.

This study was subject to both strengths and limitations. The main strength was these living, breathing words coming from the strong narrative of four brilliant women. The main limitation was the need for more inclusivity within this research and having a wide range of parents, coming from different communities be involved. For what this study was though, I do believe it is beneficial to the parenting and social work community.

It is imperative to see the impacts of this AOP, feminist knowledge occupying homes and families and children. We, as social workers discuss all the time how we can utilize the theories and frameworks we are taught; here in the pages of this MRP and the lives of these four women; Yejide, London, Valerie and Nneoma is an amazing existing example. 
I think there is a need for further research in this area, I mentioned earlier about the relationship between survivorship and feminist parenting. I think this would be an interesting place to begin to look further into the roots of feminist parenting. Additionally, I think more voices, of people with different lived experiences and identities, need to be heard from and added to this knowledge. I think there is much more information here and promoting additional research would be beneficial to this area. These are the adults of tomorrow. We need to invest in their learning and the types of values and beliefs they are being brought up with. Again, if we want change, these pedagogies have to be instilled before these youths become university students, if they do. Change starts now. Change starts with children. I want to emphasize again, this type of thinking and knowledge can legitimately save lives in today's climate. Feminist parenting may be the spark that invokes the change that can hopefully save us all. 


\section{APPENDIX A. RECRUITMENT FLYER}

\section{Exploring the current practices, that feminist parents are utilizing, to raise critically engaged, socially conscious children.}

\section{Looking for 5 Feminist Parents! Are You:}

- A self-identified, feminist parent?

- $\quad$ Over 18 years old?

If you answered yes to the above questions you are invited to volunteer in this study, exploring day to day practices of feminist parents!

You will be asked to meet for an interview, at Ryerson University OR a public library near you, where you can share your experiences being a feminist parent.

The questions will cover topics around feminist identity and how that identity interacts with raising children.

Your participation will involve one interview, lasting approximately 1 hour. You will also receive a copy of the research when it is completed.

There is no payment or reimbursement for your time.

If you are interested in participating in this study or for more information, please contact:

Shelleena Maidment, BA, BSW

I am a graduate student and this study is in partial fulfillment of my MSW

School of Social Work

Email: shelleena.maidment@ryerson.ca

My supervisor is Susan Preston, BSW, MSW, PhD

Faculty in the School of Social Work at Ryerson University

susan.preston@ryerson.ca

This research study has been reviewed and approved by the Ryerson University Research Ethics Board

APPENDIX B. CONSENT FORM
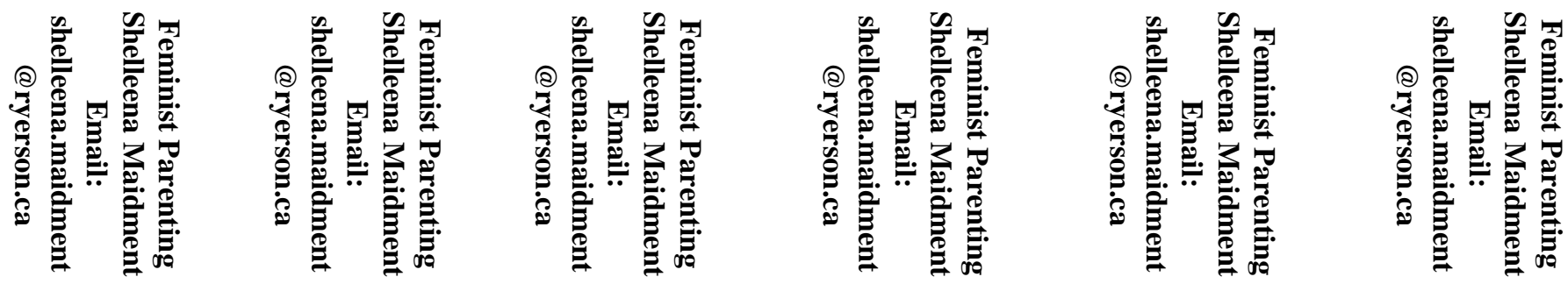


\section{Ryerson University \\ Consent Agreement}

You are being invited to participate in a research study. Please read this consent form so that you understand what your participation will involve. Before you consent to participate, please ask any questions to be sure you understand what your participation will involve.

\section{FEMINIST PARENTING:}

\section{Exploring the current practices, that feminist parents are utilizing, to raise critically engaged, socially conscious children.}

\section{INVESTIGATORS:}

This research study is being conducted by Shelleena Maidment, a graduate student, under the supervision of Susan Preston, who is faculty in the School of Social Work at Ryerson University.

If you have any questions or concerns about the research, please feel free to contact Shelleena Maidment shelleena.maidment@ryerson.ca

\section{PURPOSE OF THE STUDY:}

The purpose of this study is to explore the day to day practices of feminist parents. I am recruiting 3-5 participants for this study. The eligibility criteria I am looking for is that you are a self-identified feminist and a parent and over the age of 18 years old. The results of this research will contribute to a major research paper within the School of Social Work.

\section{WHAT PARTICIPATION MEANS:}

If you volunteer to participate in this study, you will be asked to do the following things:

- Read through this consent form

- If you choose to participate at this time, we will set up a meeting date, at a location that will be agreed upon (possible meeting locations: Ryerson University or a room in a public library that ensures aural and visual privacy)

- Following this, an interview will take place (this will take approximately 1 hour of your time) in which I will be asking questions about the practices of feminist parenting that you engage in and the reasons behind it, which will be audio-recorded. An example of some questions are; why is being a feminist parent important to you? How has parenting been an act of resistance for you? Do you believe gender is socially constructed and how have you handled that?

- If comfortable, you can write out on paper the answer to, "I am a feminist parent because..." These answers would then be photographed and may be used within dissemination, continually keeping confidentiality.

- After the interview is finished, the audio recordings will be transcribed. If you wish, I will send it to you for you to review and edit as you wish (I will give participants 3 days to edit if they choose.)

- When I am completely finished this research, you have an option for me to send you a copy. 


\section{POTENTIAL BENEFITS:}

Benefits to participants may be to share their pedagogy on parenting and their feminist ideals and worldviews. Feminist parenting is an outlier in the world of parenting, therefore we are contributing to a counter discourse. I hope that this statement may make a contribution to the literature. I cannot guarantee, however, that you will receive any benefits from participating in this study.

\section{WHAT ARE THE POTENTIAL RISKS TO YOU AS A PARTICIPANT?}

There are very low and minimal risks in this study. However, we are discussing topics on marginalized communities, as well as your parenting style, so you may experience discomfort when speaking on some subjects. If you begin to feel uncomfortable, you may skip answering a question or stop participation, either temporarily or permanently.

\section{CONFIDENTIALITY:}

Your confidentiality will be maintained. Myself and my supervisor will be the only researchers that will have any access to your data and information. This will stay in a password secured computer. When writing the research, I will use a pseudonym, in place of your name.

I will store the data until the research is completed and I have handed the final MRP in to Ryerson University, no later than September 1, 2017. Information will not go to any other party or researcher.

I will be audio-recording the interviews, so that I can give you as a participant, my full attention. These audio-recordings will then be transcribed, so I can utilize the written data. You have an option to review/edit the transcripts, once they are done being transcribed. The recording will also be stored on a password secured computer and only I will have access to them. These recordings will be destroyed when my final submission is handed in, no later than September 1, 2017.

\section{INCENTIVES FOR PARTICIPATION:}

There are no incentives for this research study, you will not be paid to participate.

\section{COSTS TO PARTICIPATION:}

I cannot provide any reimbursement for any costs, however I will be happy to accommodate by travelling to you.

\section{VOLUNTARY PARTICIPATION AND WITHDRAWAL:}

Participation in this study is completely voluntary. You can choose whether to be in this study or not. If any question makes you uncomfortable, you can skip that question. You may stop participating at any time, up until 3 weeks after your interview, due to time and data analysis. If you choose to stop participating, before this time, you may also choose to not have your data included in the study. Your choice of whether or not to participate will not influence your future relations with Ryerson University or the investigator (Shelleena Maidment) involved in the research. 
QUESTIONS ABOUT THE STUDY: If you have any questions about the research now, please ask. If you have questions later about the research, you may contact.

\author{
Shelleena Maidment \\ B.A., BSW \\ shelleena.maidment@ryerson.ca \\ Susan Preston \\ BSW, MSW, PhD \\ susan.preston@ryerson.ca
}

This study has been reviewed by the Ryerson University Research Ethics Board. If you have questions regarding your rights as a participant in this study please contact:

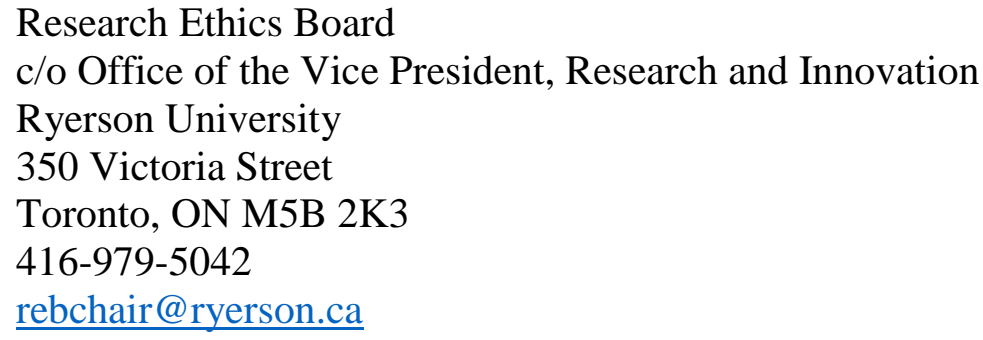

\title{
FEMINIST PARENTING
}

\section{CONFIRMATION OF AGREEMENT:}

Your signature below indicates that you have read the information in this agreement and have had a chance to ask any questions you have about the study. Your signature also indicates that you agree to participate in the study and have been told that you can change your mind and withdraw your consent to participate at any time. You have been given a copy of this agreement. You have been told that by signing this consent agreement you are not giving up any of your legal rights.

Name of Participant (please print)

Signature of Participant

Date

I agree to be audio-recorded for the purposes of this study. I understand how these recordings will be stored and destroyed. 
$\square \quad$ I would like to review my transcript; in person, by mail or via email. (please circle)

$\square$ I would like a hard copy or e-copy (please circle) of this research, when it is complete. 


\section{APPENDIX C. INTERVIEW QUESTIONS}

\section{Feminist Parenting}

\section{Demographics}

1. How old are you?

2. How do you identify in terms of race, sexuality and gender?

3. How many children do you have?

4. How old are they?

5. What is your relationship status?

\section{Feminist Identity}

6. What does feminist, as an identity, mean to you?

\section{Growing Up}

7. How does your feminism fit with the family you grew up in?

\section{Feminist Experiences of Parenting}

8. How has identifying yourself as a feminist had implications for how you understand parenting and participate in your family?

9. Why is it important for you, to parent in a feminist informed way?

10. As a feminist parent, do you believe you are resisting other styles of parenting?

11. How have people close to you reacted to your choice of parenting from a feminist lens?

12. What have you found are the biggest challenges of identifying and parenting as a feminist?

13. How have outside institutions (schools, daycare) impacted your feminist parenting?

\section{Raising Children from a Feminist Lens}

14. Do you believe gender is socially constructed?

If so, how have you dealt with this idea, when raising your child(ren)?

15. How are the gender roles in your home divided, in terms of parenting, chores and work?

16. What would you say are important strategies for feminist parents to use when raising children?

17. Do you believe in power-sharing with your children?

18. How do you deal with body image?

19. How do you deal with bodily autonomy?

20. Do you promote gender equality?

If so, how?

21. How do you or how will you talk about sexuality?

22. Do you have conversations with your children on privileges and oppressions?

If so, how far do these conversations go?

23. Does your feminist parenting impact the types of toys or things that are bought for your child(ren)?

24 . How do you think your feminist parenting has influenced or impacted your child(ren)?

25 . Is there anything that you would like to add or ask me? 


\section{References}

Brown, L. A., \& Strega, S. (2015). Research as resistance: Revisiting critical, indigenous, and anti-oppressive approaches (2nd ed.). Toronto, ON: Canadian Scholars' Press.

Espineira, K., \& Bourcier, M. (2016). Transfeminism: Something else, somewhere else. Transgender Studies Quarterly, 3(1-2), 84-94. doi:10.1215/23289252-3334247

Fraser, H., \& MacDougall, C. (2016). Doing narrative feminist research: Intersections and challenges. Qualitative Social Work, 16(2), 1-15. doi:10.1177/1473325016658114

Friedman, M. (2015). Unpacking MILF: Exploring motherhood, sexuality and feminism. Atlantis: Critical Studies in Gender, Culture \& Social Justice, 36(2), 49-60.

Green, F. J. (2015). Re-conceptualising motherhood: Reaching back to move forward. Journal of Family Studies, 21(3), 196-207. doi:10.1080/13229400.2015.1086666

Green, F. J. (2009). Feminist mothering: Challenging gender inequality by resisting the institution of motherhood and raising children to be critical agents of social change. Socialist Studies/Études Socialistes, 1(1), 83-99.

Green, F.J. (2006). Developing a feminist motherline: Reflections on a decade of feminist parenting. Journal of the Association for Research on Mothering, 8(1-2), 7-20.

hooks, bell. (2015). Revolutionary parenting. In Feminist theory: From margin to center (pp. 133-147). New York, NY: Routledge.

Koyama, E. (2001). The transfeminist manifesto. In R. Dicker \& A. Piepmeir (Eds.), Catching a wave: Reclaiming feminism for the twenty-first century (pp. 244-262). Boston, MA: Northeastern University Press.

Liss, M., \& Erchull, M. J. (2012). Feminism and attachment parenting: Attitudes, stereotypes, and misperceptions. Sex Roles, 67(3-4), 131-142. doi:10.1007/s11199-012-0173-z 
Mack-Canty, C., \& Wright, S. (2004). Family values as practiced by feminist parents bridging third-wave feminism and family pluralism. Journal of Family Issues, 25(7), 851-880. doi:10.1177/0192513X03261337

May, S. (2011). Mothers and sons: Feminist parenting and the conundrums of raising males. Journal of Feminist Studies in Religion, 27(2), 121-133. http://doi.org/10.2979/jfemistudreli.27.2.121

Oparah, J. (2012). Feminism and the (trans)gender entrapment of gender nonconforming prisoners. UCLA Women's Law Journal, 18, 239-271.

Ott, K. M. (2011). Feminist mothering of sons: Ethical practices for everyone. Journal of Feminist Studies in Religion, 27(2), 143-147. doi:10.2979/jfemistudreli.27.2.143

Padgett, D.K. (2008). Qualitative methods in social work research (2nd ed.). Thousand Oaks, CA: Sage.

Presser, L. (2005). Negotiating power and narrative in research: Implications for feminist methodology. Signs: Journal of Women in Culture and Society, 30(4), 2067-2090.

Riessman, C. K. (2005). Narrative analysis. In N. Kelly, C. Horrocks, K. Milnes, B. Roberts, \& D. Robinson (Eds.), Narrative, memory \& everyday life (pp. 1-7_. Huddersfield, UK: University of Huddersfield. Retrieved from http://citeseerx.ist.psu.edu/viewdoc/download?doi=10.1.1.470.1392\&rep=rep1\&type=pdf

Schmeiser, P. (2011). Raising Sam: Mothering as a secular feminist scholar of religion. Journal of Feminist Studies in Religion, 27(2), 148-152. doi:10.2979/jfemistudreli.27.2.148

Serano, J. (2007). Whipping girl: A transsexual woman on sexism and the scapegoating of femininity. Berkeley, CA: Seal. 
Silva, J. M., \& Ornat, M. J. (2016). Transfeminism and decolonial thought. Transgender Studies Quarterly, 3(1-2), 220-227. doi:10.1215/23289252-3334415

White, A. (2006). African American feminist fathers' narratives of parenting. Journal of Black Psychology, 32(1), 43-71. Retrieved from http://resolver.scholarsportal.info/resolve/00957984/v32i0001/43_aaffnop.xml

Wong, Y. (2004). Knowing through discomfort: A mindfulness-based critical social work pedagogy. Critical Social Work, 5(1), 1-9.

Wu, Y. (2012). Feminist parenting in controversy: How the British press covers Nick Clegg doing the "school run". Feminist Media Studies, 12(1), 143-148. doi:10.1080/14680777.2011.640008 